This item was submitted to Loughborough's Research Repository by the author.

Items in Figshare are protected by copyright, with all rights reserved, unless otherwise indicated.

\title{
Production and preservation of the smallest drumlins
}

\section{PLEASE CITE THE PUBLISHED VERSION}

https://doi.org/10.1080/11035897.2018.1457714

\section{PUBLISHER}

(C) Geologiska Foreningen. Published by Taylor and Francis

\section{VERSION}

AM (Accepted Manuscript)

\section{PUBLISHER STATEMENT}

This work is made available according to the conditions of the Creative Commons Attribution-NonCommercialNoDerivatives 4.0 International (CC BY-NC-ND 4.0) licence. Full details of this licence are available at: https://creativecommons.org/licenses/by-nc-nd/4.0/

\section{LICENCE}

CC BY-NC-ND 4.0

\section{REPOSITORY RECORD}

Hillier, John, Ivar Benediktsson, Tom Dowling, and Anders Schomacker. 2019. "Production and Preservation of the Smallest Drumlins". figshare. https://hdl.handle.net/2134/32360. 


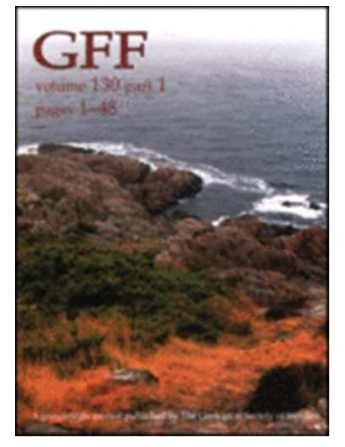

\section{Production and preservation of the smallest drumlins}

\begin{tabular}{|r|l|}
\hline Journal: & GFF \\
\hline Manuscript ID & SGFF-2017-0047.R1 \\
\hline Danuscript Type: & Special Issue \\
\hline Complete List of Authors: & $\begin{array}{l}\text { Hillier, John; Loughborough University, } \\
\text { Benediktsson, Ivar; University of Iceland, Institute of Earth Sciences } \\
\text { Dowling, Tom; Geospatial Insight Ltd. } \\
\text { Schomacker, Anders; UiT The Arctic University of Norway, Department of } \\
\text { Geosciences }\end{array}$ \\
\hline Keywords: & $\begin{array}{l}\text { Drumlin, Iceland, Múlajökull, size-frequency distribution, landform } \\
\text { mapping, subglacial bedform, morphometry }\end{array}$ \\
\hline \multicolumn{2}{|c}{} \\
\hline
\end{tabular}

SCHOLARONE $^{\text {m }}$

Manuscripts 


\section{Production and preservation of the smallest drumlins}

2

$3 \quad$ Hillier $^{1}$, J. K., Benediktsson ${ }^{2}$, Í.Ö., Dowling ${ }^{3}$, T.P.F., Schomacker ${ }^{4}$, A.,

4

$5{ }^{1}$ Department of Geography, Loughborough University, UK. j.hillier@lboro.ac.uk, ++44 1509

6223727.

$7 \quad{ }^{2}$ Institute of Earth Sciences, University of Iceland, Iceland. ivarben@hi.is, +354 5254605.

$8 \quad{ }^{3}$ Geospatial Insight Ltd., Coleshill, B46 3AD, UK. tpfdowling@gmail.com, +44 7879089506.

$9 \quad{ }^{4}$ Department of Geosciences, UiT The Arctic University of Norway, Norway.

10 anders.schomacker@uit.no,+4795523464.

12 Acknowledgements

13

14 We thank the organisers of the 'Beauty of Drumlins' symposium for bringing the authors 15 together in Lund, Sweden, May 2017, in honour of Professor Per Möller upon his retirement. 16 We are grateful to Chris Stokes and an anonymous reviewer for their insightful comments, 17 which improved the manuscript. 
20

21

22

23

24

25

26

27

28

29

30

31

32

33

34

35

36

37

38

39

40

41

42

43

44

45

46

\section{Production and preservation of the smallest drumlins}

\section{Abstract}

Few very small drumlins are typically mapped in previously glaciated landscapes, which might be an important signature of subglacial processes or an observational artefact. 143 newly emergent drumlins, recently sculpted by the Múlajökull glacier, have been mapped using highresolution LiDAR and aerial photographs in addition to field surveying. In this paper, these are

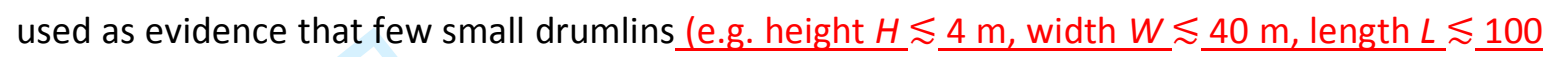
$\underline{\mathrm{m})}$ are produced; at least, few survive to pass outside the ice margin $\underline{\text { in }}$ this actively forming drumlin field. Specifically, the lack of a multitude of small features seen in other landforms (e.g. volcanoes) is argued not to be due to i) Digital Elevation Model (DEM) resolution or quality, ii) mapper ability in complex (i.e. anthropogenically cluttered or vegetated) landscapes, or iii) post-glacial degradation at this site. So, whilst detection ability must still be at least acknowledged in drumlin mapping, and ideally corrected for in quantitative analyses, this observation can now be firmly taken as a constraint upon drumlin formation models (i.e. statistical, conceptual, or numerical ice flow). Our preferred explanation for the scarcity of small drumlins, at least at sites similar to Múlajökull (i.e. ice lobes with near-margin drumlin genesis), is that they form stochastically during multiple surge cycles, evolving from wide and gentle pre-existing undulations by increasing rapidly in amplitude before significant streamlining occurs.

\section{Keywords}

Drumlin, size-frequency distribution, Múlajökull, Iceland, landform mapping, subglacial bedform, morphometry. 


\section{Introduction}

Drumlins are subglacial bedforms aligned parallel to ice flow, created by interactions in the icesediment-water system underneath glaciers or ice-sheets [e.g. Menzies, 1979; Clark et al., 2009; Benn and Evans, 2010]. Their mode of formation remains enigmatic and debated [Smalley and Unwin, 1968; Menzies, 1979; Shaw, 1983; Boulton and Hindmarsh, 1987; Hindmarsh, 1998; Fowler, 2000], primarily because the bases of modern ice sheets are inaccessible, which results in few direct observations [King et al., 2007; Smith and Murray, 2009]. Mapped morphometrics of the numerous (i.e. $\gg 10,000$ ) drumlins formed during past glaciations_[e.g. Hättestrand et al., 2004; Storrar and Stokes, 2007; MacLachlan and Eyles, 2013] are therefore key to understanding the subglacial interface, despite less readily yielding secure conclusions about the dynamics and mechanics of former ice sheets.

Observations of bedform position and morphology are used to indicate ice extent or flow direction [e.g. Hollingsworth, 1931; Livingstone et al., 2008], for example to assess consistency with numerical ice sheet models [Evans et al., 2009]. Elongated bedforms have also been linked to fast ice flow [Clark, 1993; Stokes and Clark, 2002]. However, it is rare to directly or quantitatively use bedform morphometrics to consider the mechanics of ice-sediment interaction and flow [e.g. Chorley, 1959; Smalley and Warburton, 1994]. As a step to bridging this gap Hillier et al. [2013] proposed a conceptual model to explain the size-distributions of subglacial bedforms in terms of stochastic ice-sediment-water interaction; subsequently, a variety of statistical models have been developed to formalize the postulated stochastic behaviour [Fowler et al., 2013; Hillier et al., 2016]. Hence, as a theoretical basis emerges for interrogating bedform size observations in more depth, high-quality morphometric data are becoming more important.

Drumlins have heights $(H)$ (a.k.a. amplitude) ranging up to a few 10 s of $m$, their widths $(W)$ are of the order of 100s of $\mathrm{m}$, and they have lengths $(L)$ of up to a few km [e.g. Hollingsworth, 1931; Hättestrand et al., 2004; Clark et al., 2009]. Size distributions can be summarized by basic statistics (e.g. mean, minimum, maximum, modal class, skew) [e.g. Clark et al., 2009], or by one- or two-parameter functions (i.e. exponential, log-Normal, Gamma) [Fowler et al., 2013; Hillier et al., 2013, 2016] approximating a ubiquitous typical shape (Figure 1). There are few small bedforms mapped, a modal peak at sizes above this forming a 'roll-over', and an approximately exponential tail of frequencies decreasing towards the largest sizes. This is true 
81 for both aggregated data and, importantly, individual flow sets that likely represent

82 glaciological conditions at a particular location and time [Hillier et al., 2013, 2016].

83

84

85

86

87

88

89

90

91

92

93

94

95

96

97

98

99

100

101

102

103

104

105

106

107

108

109

110

111

112

113

114

\section{FIG 1 HERE}

The roll-over and absence of very small forms might be an important signature of subglacial

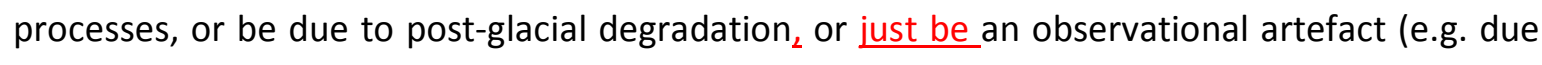
to low DEM resolution) [see Hillier et al., 2013]. If this absence is real it could be a key constraint on drumlin formation, for instance distinguishing between statistical models built to represent various glaciologically reasonable hypotheses [Hillier et al., 2016]. Illustratively, for landslides a roll-over has been interpreted in terms of physical processes_e.g. cohesion contributing to soil stability) [e.g. Malamud et al., 2004; Frattini and Crosta, 2013] and, contrastingly, elsewhere considered as observational under-sampling [e.g. Stark and Hovius, 2001; Ten Brink, 2006]. Submarine volcanoes tend to have no roll-over demonstrating that natural processes can also produce sizes that can be approximated by simpler distributions such as exponential or power-law [e.g. Smith and Jordan, 1987; Scheirer and Macdonald, 1995; Rappaport et al., 1997; Hillier and Watts, 2007; Bohnensteihl et al., 2008].

In terms of drumlin mapping, Spagnolo et al. [2012] assert that a small drumlin of $2.1 \mathrm{~m}$ relief $(H=2.1, W=150, L=430)$ is reliably mapped in the $5 \mathrm{~m}$ resolution NEXTmap Britain ${ }^{\text {TM }}$ InSARderived DEM. Indeed, a field visit is used to verify its existence. Using the same data product, Hillier et al. [2014] use synthetic landscapes to illustrate that as much as $75 \%$ of the smallest drumlins might be missed during mapping in complex landscapes (i.e. with anthropogenic clutter and trees), and that amplitude (or height) is the key variable governing detectability (Figure 2). The designed landscapes of Hillier et al. [2014] were Digital Elevation Models (DEMs) of a real glaciated area that had 173 drumlins of realistic morphology and size placed within them. Without prior sight of the drumlins' locations, 27 operators then mapped the area to assess their effectiveness. Their study site near Loch Lomond is challenging to map, so this perhaps illustrates a conservative 'worst case' for under-detection. Thus whilst a 'small' feature ${ }_{L}$ $\underline{\text { defined here to be less than about half the modal size of a dataset, }}$ can be mapped ${ }_{2}$ an open question remains as to the completeness of mapping at these small sizes and its impact on sizedistributions and inferences from them.

FIG 2 HERE

URL: http://mc.manuscriptcentral.com/sgff Email: Christian.Skovsted@nrm.se 
116 Individual drumlins, or small groups of drumlins, have been described under ice streams [King et al., 2007; e.g. Smith et al., 2007] and in front of contemporary glaciers in Alaska [Haselton, 118 1966], Antarctica [e.g. Rabassa, 1987], Switzerland [van der Meer, 1983] and Iceland [e.g. 119 Boulton, 1987; Krüger, 1987; Evans and Twigg, 2002]. The number (i.e. 143) of drumlins in the 120 flow set at the Múlajökull surge-type piedmont glacier in central Iceland is large for a contemporary glacier and, as yet, unique for a large and active drumlin field in being both currently sub-aerial and the subject of detailed geomorphological, sedimentological and stratigraphic analysis (Figure 3) [e.g. Johnson et al., 2010; Benediktsson et al., 2016]. It is therefore a study site with the power to yield novel insights, but differences across the site in simple descriptive measures of the drumlin morphometrics (e.g. mean W) [e.g. Benediktsson et al., 2016] have not yet been verified by statistical testing, nor have the size-frequency

In this paper, 143 newly emergent drumlins recently created by the Múlajökull glacier (Figure 3c) are used to understand the production and preservation of the smallest drumlins. They have had little time to degrade post-glacially, have no 'clutter' on their surfaces (e.g. trees, houses), and are mapped in high-resolution data supported by extensive ground-truthing during fieldwork [Benediktsson et al., 2016], removing many sources of observational ambiguity. Error bars, statistical significances, and distribution parameters (i.e. exponential, log-Normal,

\section{FIG 3 HERE}

\section{Study area}

146 Múlajökull is a surge-type glacier in the southern part of the Hofsjökull ice cap in central Iceland [Björnsson and Pálsson, 2008] with surges recorded in 1924, 1954, 1966, 1971, 1978-79, 1986, 1992, and 2008 [Björnsson, 2009]. The glacier forefield is relatively flat; it dips gently in a down- 
149 ice direction away from the glacier at approximately $\underline{1}^{\circ}$ [McCracken et al., 2016], is at roughly $150600 \mathrm{~m}$ above sea level, and contains 132 fully-exposed and 11 partially-exposed drumlins of 151 roughly elliptical planform interspersed with small lakes [Jónsson et al., 2014; Benediktsson et

152 al., 2016]. Even more drumlins have been reported to be beneath Múlajökull's margin, but 153 154 limited to a 0.5-0.7 km wide zone inside the 2015 ice margin [Lamsters et al., 2016]. Beyond this limit, farther from the ice margin, the GPR survey reveals no drumlins [e.g. Fig. 4 of Lamsters et al., 2016] $]_{L}$ and in the segment surveyed the bed starts dipping up ice into the prominent, $\sim 130 \mathrm{~m}$ deep subglacial overdeepening located in the centre of the Múlajökull ice lobe [Björnsson, 1986]. The exposed drumlins comprise multiple till beds [e.g. Johnson et al., 2010]. As such, they are examples of mainly till-cored drumlins rather than other variants such as 'crag-and-tail' [Phillips et al., 2010; Stokes et al., 2011; Dowling et al., 2015]. Surface till terminating at the 1992 moraine, field evidence of stagnant ice that could not have deposited substantive thicknesses of till after the 1992 surge (e.g. preserved flutes), non-deposition of till during small winter advances, and till shear fabrics that conform to drumlin morphology all indicate that tills were deposited during surges [Johnson et al., 2010; McCracken et al., 2016]. The youngest till bed roughly replicates the drumlins' form and truncates stratigraphically lower units, particularly on the drumlins' flanks and heads [Johnson et al., 2010; Benediktsson et al., 2016]. This indicates that during surge-cycles drumlins likely get progressively narrower and higher [Benediktsson et al., 2016].

The drumlins' reported sizes [Johnson et al., 2010; Jónsson et al., 2014; Benediktsson et al., 2016] are similar to widespread and well-studied Pleistocene drumlin fields [Patterson and Hooke, 1995; Clark et al., 2009; Hillier et al., 2013]. Ice proximal drumlins are more elongate than distal ones [e.g. Benediktsson et al., 2016]. This study area, therefore, despite differences in spatial extent, perhaps most directly relates to Pleistocene drumlin fields where elongation ratio (i.e. $L / W$ ) increases up-ice, namely away from a margin related to a relevant maximum ice extent [e.g. Colgan and Mickelson, 1997; Stokes and Clark, 2003].

177 This drumlin field is argued to be 'active' in the sense that it is sculpted by the current glacial 178 regime of repeated surges and intervening quiescent phases_[e.g. McCracken et al., 2016], most 179 recently and directly evidenced by a till from the 2008 surge lying atop an erosional surface [i.e. 180 Johnson et al., 2010; Benediktsson et al., 2016]. Subglacial morphological dynamics at any given 181 location may be punctuated by periods without change, and therefore be inactive at any exact 
182 instant, even under flowing ice-streams. Thus, 'active' does not refer to changes this minute or even today, but relates to present conditions and a time-scale is implied, in this case decades.

The foreland of Múlajökull is comprised of minimally vegetated and essentially homogenous till and outwash deposits [Jónsson et al., 2014; Benediktsson et al., 2016]. Specifically, there is no significant vegetation inside the Little Ice Age (LIA) moraine that bounds the immediate foreland and even though the vegetation cover on the moraine and beyond is continuous, it is 189 limited to short grasses and shrubs under a few $10 \mathrm{~s}$ of $\mathrm{cm}$ in height (Figure 4). There has been 190 no anthropogenic disturbance (e.g. houses or infrastructure) in the area. Even drumlins 191 proximal to the glacier are not ice-cored [Benediktsson et al., 2016]. There are no large 192 topographic variations that might dominate ice flow patterns, such as the bedrock ridge near

The maximum Holocene extent of Múlajökull was reached in the LIA (1717-1758), recorded by the Arnarfellsmúlar terminal moraine [Benediktsson et al., 2015]. The most substantial surges since 1924 (i.e. 1954, 1971, 1986, 1992) have terminated approximately at the remaining 1992 end moraine_[Björnsson et al., 2003; Johnson et al., 2010]. Also, a small surge in 2008 was observed to create a significant ice-cored moraine just distal of the present ice margin_[Jónsson et al., 2014; Benediktsson et al., 2016]. As such, a series of moraines outside the 1992 limit, including an overridden moraine ${ }_{L}$ inboard of the Arnarfellsmúlar terminal moraine suggest that this area also experienced multiple surges during the LIA both before and after the maximum extent in the early to mid-1700s_[Jónsson et al., 2014; Benediktsson et al., 2015]. Thus, it is convenient to divide the forefield into two zones 'inside' and 'outside' the 1992 moraine based on historical surge activity. The area inside is reported to contain more elongate_drumlins than outside, with respective mean elongation ratios (i.e. L/W) of 3.0 and 1.9 [Benediktsson et al., 2016]. It has been hypothesized [Johnson et al., 2010; Jónsson et al., 2014; Benediktsson et al., 2016] that distal drumlins have been shaped by fewer surges than those closer to the glacier. At Múlajökull surges deposit till with a sedimentology and stratigraphy that imply net aggradation [Johnson et al., 2010; McCracken et al., 2016], so inferred thicker proglacial sediment near to the current ice margin implies more geomorphically active surges there [McCracken et al., 2016]. This inference is supported by a number of lines of evidence. Topography dips away from the glacier aligned with flow parallel features (e.g. flutes) and perpendicular to terminal 
216 moraines, indicating that it reflects ice flow rather than other controls. A break in slope exists at

217

218

219

220

221

222

223

224

225

226

227

228

229

230

231

232

233

234

235

236

237

238

239

240

241

242

243

244

245

246

247

248

the 1992 moraine, where the four most recent large surges have stopped. There is no evidence for bedrock control of slope, and if it is postulated to be causing up-ice dips at this site its influence is demonstrated to be subservient to ice flow by the overdeepening just upstream of the current ice margin [Björnsson, 1986; Lamsters et al., 2016]. Thus, a powerful aspect of the Múlajökull site is that relatively strong constraints exist on the timing and duration of geomorphic work in two zones, which is rare. This constraint allows predictions by models of how subglacial bedforms (e.g. drumlins) progressively evolve with time to be considered against observations that have quite low levels of ambiguity.

Neither sedimentology nor stratigraphy yet directly constrain drumlins' elongation during surge-cycles. Till fabrics and bulk densities indicate that inter-drumlin areas have experienced higher maximum effective stresses ( 100 kPa), argued to represent quiescent periods under the assumption of effective and channelized drainage at these times [McCracken et al., 2016]. Then, as in other models [e.g. Hindmarsh, 1998; Chapwanya et al., 2011], increased effective shear $\underline{\text { stresses are taken to indicate higher rates of sediment transport. The basal stress distribution is }}$ asserted to be compatible with a crevasse pattern at the ice front, which is strongly related to the spatial pattern of the drumlins [Johnson et al., 2010; Benediktsson et al., 2016; McCracken et al., 2016], but the mechanics of causal relationship remain conjectural. The available observations have been consolidated and reconciled into a conceptual model [Johnson et al., 2010; Jónsson et al., 2014; Benediktsson et al., 2016; McCracken et al., 2016], an extreme precis of which follows: Although sediment transport mechanisms are not uniquely constrained, surges deposit drapes of till everywhere, then in each intervening quiescent period there is erosion in the inter-drumlin areas, processes that combine to lead to increases in $H$ and $L$ but a decrease in W. A mathematical model has been developed to formalize this [Iverson et al., 2017]. GPR data [Lamsters et al., 2016] and the Múlajökull drumlins' proximity to the LIA terminal moraine dictate that these models are based on, and therefore most directly constrain, near-margin (i.e. $<1-2 \mathrm{~km}$ ) drumlin formation.

\section{FIG 4 HERE}

\section{Data and mapping}


249 Johnson et al. [2010] use $1 \mathrm{~m}$ resolution gridding of airborne laser scanning (i.e. LiDAR) data 250 from 2008 to map $>50$ drumlins inside the 1992 moraine, which are 90-320 m long $(\bar{L}=185 \mathrm{~m})$, $25130-105 \mathrm{~m}$ wide $(\bar{W}=64 \mathrm{~m})$, and 5-10 $\mathrm{m}$ in relief. Mean elongation ratio is 3.0. Drumlins outside 252 the 1992 moraine were first mapped by Jónsson et al [2014] from a $3 \mathrm{~m}$ resolution DEM that 253 was created from aerial stereophotographs taken in 1995, increasing the total number of drumlins to 110 . The size ranges increased, e.g. $W$ values are $20-180 \mathrm{~m}$ as is expected of a larger sample. Most recently, 143 drumlins were mapped from $0.5 \mathrm{~m}$ resolution LiDAR collected in 2013 [Benediktsson et al., 2016] (see Supplementary Material), reporting broadly comparable morphometrics, which are similar to widespread and well-studied Pleistocene drumlin fields [Patterson and Hooke, 1995; Ó Cofaigh et al., 2010; Hillier et al., 2013]. The existence and conformity to expectations of shape of all drumlins mapped were verified by inspection in the field, and no additional small drumlins were identified whilst on the ground 262 [Johnson et al., 2010; Jónsson et al., 2014; Benediktsson et al., 2016].

A first source of uncertainty in the drumlin morphometrics at Múlajökull might be DEM resolution or quality. Whilst the $1995 \mathrm{DEM}$ is based on stereophotogrammetry and is of a low resolution and accuracy [Jónsson et al., 2014], LiDAR data are widely regarded as a good basis for producing high quality DEMs in glacial and pro-glacial areas [e.g. Favey et al., 1999]. Even the 2008 LiDAR data have a point density of $0.33 \mathrm{~m}^{-2}$, an average of 10 data per $5 \times 5 \mathrm{~m}$ grid cell, and estimated horizontal accuracy of $<0.5 \mathrm{~m}$ [Jóhannesson et al., 2014] much below drumlins' planform dimensions (i.e. $L, W$ ). This assertion is supported by close agreement (i.e. mean vertical difference of $0.132 \mathrm{~m}$ ) between the 2008 and 2013 LiDAR DEMs on two selected profiles (Figure 5). Of particular interest is the inter-survey agreement between the size of the undulations shown, with variance in amplitude on the order of $0.1 \mathrm{~m}$, which is less than the $H$ of even the smallest mapped drumlins. Thus, uncertainty in drumlin morphometrics from DEM creation will be small. Accurate DEM creation is, at least in part, due to minimal vegetation cover. Vegetation present within the area of the 2013 LiDAR DEM is mainly in the form of mosses that are limited to streams, shallow ponds and wet ground (Figure 4), and will typically

FIG 5 HERE be penetrated by the LiDAR sensing method.

A second potential discrepancy between mapped drumlins and the population of subglacially produced forms they preserve and reflect is post-glacial alteration. Plan view comparison 
283

284

285

286

287

288

289

290

291

292

293

294

295

296

297

298

299

300

301

302

303

304

305

306

307

308

309

310

311

312

313

314

315

316

(Figure 6) indicates that surface alteration in the foreland between 2008 and 2013 is relatively small (i.e. $<0.5 \mathrm{~m}$, dark green) with respect to drumlin dimensions. Exceptions to this are readily explicable, namely the lowering of the level of ice-marginal lakes by $0.5-2 \mathrm{~m}$ [Benediktsson et al., 2016] and the degradation of the 2008 ice-cored moraine, which is superimposed on some drumlins. In terms of ground-truthing, terrain profiles surveyed using a TopCon GTS-236N total station between 2011 and 2014 show 0.4-0.8 m lowering of the 2008 ice-cored moraine crest due to melting, but negligible (i.e. $<0.1 \mathrm{~m}$ ) surface alteration on drumlin surfaces outside the degrading moraine. A similar conclusion is reached by comparing change between 2008 and 2013 for 'high' and 'low' stretches of profiles P1 and P2 extracted from the LiDAR data in locations shown on Figure 5. In P1 high and low areas changed by +0.073 and $+0.055 \mathrm{~m}$, respectively, apparently indicating an amplitude increase of $\sim 2 \mathrm{~cm}$, which is inconsistent with gravity driven mass-wasting. In P2, an amplitude decrease of $\sim 1 \mathrm{~cm}$ is implied. Taken together, minimal change at the limit of observational resolution is demonstrated. This is consistent with stability at bedform scales (i.e. few 100 s of $\mathrm{m}$ ) over decades observed in other Icelandic till plains such as at Brúarjökull [Korsgaard et al., 2015]. Thus, there is no evidence of post-glacial degradation substantively impacting drumlins at this site.

\section{FIG 6 HERE}

A third source of disagreement has the potential to arise in the methods used in mapping [Podwysocki et al., 1975; Siegal and Short, 1977; Smith and Clark, 2005; Gardin et al., 2011; Ardelean et al., 2013; Van Coillie et al., 2014] and then calculating the metrics of drumlins [e.g. Spagnolo et al., 2012; Hillier and Smith, 2014; Jorge and Brennand, 2017]. During fieldwork [e.g. Jónsson et al., 2014] an ambiguity of 1-10 m was identified in setting the location of boundaries that were not at shorelines, making a GIS approach [e.g. see Smith et al., 2006; Spagnolo et al., 2012] the most consistent and reproducible way of delimiting drumlins. Conceptual ambiguity exists where lakes conceal the land surface, with a debate as to whether drumlins are best defined as isolated features or waveforms [Stokes et al., 2013b] $]_{2}$ but no DEM mapping approach is a solution for this. Benediktsson et al. [2016] identified and mapped the drumlins at a scale of 1:3000-1:6000 in ArcGIS 10.2.2 using a hillshade model of the $0.5 \mathrm{~m}$ LiDAR DEM from 2013 with 1.5-4 times vertical exaggeration, 20-30ºlar angle and illumination azimuths at $45^{\circ}$ and $315^{\circ}$. A combination of slope analysis and visual inspection was used to delimit the drumlins at a break in slope, which could either be abrupt (e.g. lakes, outwash) or gradual. Only where both axes of a putative drumlin (long, short) were upstanding from the landscape was 
317 the planform shape considered delineated and a drumlin defined [Dowling, 2016]. However, if small forms have similar morphology to their larger companions, this will not impact the size-

Drumlin length $(L)$ and width $(W)$ were derived by measuring the length of the longest lines parallel and perpendicular to ice flow, respectively, within each drumlin_[Benediktsson et al., 2016]. Being recently deglaciated, ice-flow direction was determined by flutes and other streamlining in the forefield. Drumlin relief $(H)$ was defined by the range in elevation of each drumlin. Whilst this is a simple approach [e.g. see Hillier and Smith, 2012, 2014; Spagnolo et al., 2012], lakes bounding all but 3 drumlins inside the 1992 moraine make a horizontal basal plane a natural choice, with consistency requiring the same to be done outside the 1992 moraine. In this particular site, the use of drumlin elevation range to represent drumlin height (i.e. $H$ ) will cause relatively minor artefacts since the slope of the foreland is shallow (i.e. 0.007-0.023) [McCracken et al., 2016]. At least, the shape of the size distributions for $H$ (Figure 7) will likely be minimally affected (see Section 4.4).

A fourth and final source of ambiguity in drumlin morphometrics inside the 1992 moraine is the presence of pro-glacial lakes. Draining these may increase mapped estimates of $H, L$, and $W$ for lake-bounded features. The magnitude of this is difficult to constrain without additional information as it will depend on drumlin shape in the flooded areas, which is currently unknown, and is possibly influenced by lake drainage itself. However, the scarcity of many small drumlins between larger ones mapped outside the 1992 moraine indicates that this ambiguity will not impact the existence or otherwise of a roll-over in size frequency distributions.

\section{Statistical analysis of the Múlajökull drumlin dataset}

The median, range (i.e. minimum and maximum), standard deviation, and mean of drumlin sizes have been reported for Múlajökull [Benediktsson et al., 2016] but the uncertainty associated with size measurements has not. Here selected error bars, statistical significances, and distribution parameters (i.e. exponential, log-Normal, Gamma) are computed. Twoparameter distributions are a more sophisticated description of size-distributions [e.g. Hillier et al., 2013; Ely et al., 2017], and are reported for use in future compilations and analysis (Table 1).

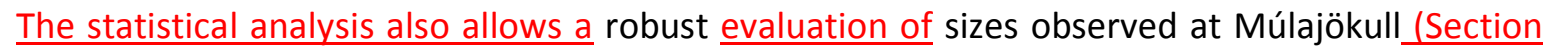
6). In particular, Section 4.1 reports error bars and sensitivity tests for the measures of central 
351 tendency (i.e. mean of $H, L$, and $W$ ) that are a key part of the design of the conceptual model at

352 Múlajökull [i.e. Johnson et al., 2010; McCracken et al., 2016; Iverson et al., 2017]. Sensitivity to

353 the measure of central tendency used (i.e. mean, median or mode) is also considered. Section

$354 \quad 4.2$ determines if a roll-over exists, thereby permitting comment on whether or not small

355 drumlins are scarce. To test posited models of drumlin formation that have been statistically

356 formalized [Fowler et al., 2013; i.e. Hillier et al., 2013] Section 4.3 summarizes key variations in

357 the relevant metrics of the two-parameter distribution. Finally, Section 4.4 considers a potential

358 systematic (i.e. not due to randomness and sampling) issue with the method used to calculate

$359 \underline{H}$.

360

361

362

363

Given the relatively small number of data inside and outside of the 1992 moraine (i.e. 77 and

55 ) it is possible that an apparent trend or observation does not actually exist (i.e. is not

statistically significant). It could arise simply due to random variation in the selection of a

sample; conceptually, observed data are a sample reflecting a parent population of what could

be produced under identical glaciological conditions. A convention of considering a $5 \%$ chance of the result occurring by random variation in sampling (i.e. $95 \%$ level, $p<0.05$ ) is arbitrary

[Wasserstein and Lazar, 2016], so both 5\% and 10\% levels are reported.

The mean (i.e. $\mu$ ) is perhaps the most commonly computed statistic for this type of bedform data, and relates to the Normal distribution (Table 1). A Welch t-test (2-tailed) confirms the observations of Benediktsson et al. [2016] that drumlins inside the 1992 moraine are longer ( $P$ $\ll 0.01)$ and narrower $(P=0.011)$ than those outside, and strengthens their view that there

375 appears to be no increase in heights.

377 All of the dimensions (i.e. $H, W, L$ ) for both data sets appear positively skewed, indicating 378 distributions with a more heavily populated right-hand tail than a Normal distribution, and 379 most of the skews (4 of 6$)$ are statistically significant $(P<0.05)$. In other words, the distributions 380 are not Normal, so a different measure of central tendency may be a more appropriate 381 indicator of where the distribution is located on the $x$-axis if plotted (e.g. Figure 1a). However, 382 there is consistency_Table 1) between measures of central tendency (i.e. mean $\_$median and mode) alleviating any concern about previous uses of the mean. 
385 386

387 388

\subsection{Existence of a roll-over}

To determine the existence, or otherwise, of a roll-over the exponential [Hillier et al., 2013], log-Normal [Fowler et al., 2013; Hillier et al., 2016] and Gamma [Hillier et al., 2016] distributions are fitted to the observations (Figure 7). Reassuringly, the variations in parameters of these distributions ( $\mu_{\underline{L}} \sigma_{\underline{L}} \underline{\underline{ }}, \alpha, \beta$ and $\lambda$ ) also show broad consistency with change in $\mu$ between the zones inside and outside the 1992 moraine. Namely, between the two areas $H$ is similar and $L$ is different, with a weaker signal for $W$ reflecting a smaller magnitude of change. Both logNormal and Gamma distributions fit the data comparably well, whilst the exponential fits the upper tail (i.e. larger forms) only and not the roll-over. In other words, there are fewer small drumlins than expected by simple extrapolation_(i.e. using the exponential) from larger $\underline{\text { drumlins, }}$ which are typically more reliably observed than smaller drumlins. For completeness, a conservative correction for under-sampling to bend the exponential model towards the data (i.e. potentially account for the roll-over) is shown (dashed grey line) to allow for a direct comparison with analyses for other areas (see Section 5). Even were this correction for cluttered, hilly, $5 \mathrm{~m}$ resolution, InSAR-derived data applicable, it is insufficient to explain the

roll-over; a factor of $x 10$ (i.e. $10 \%$ recovery) equates to 2.3 on the vertical scale, which is a $\underline{\text { natural logarithm. In short, a roll-over exists in the data from Múlajökull, indicating a scarcity of }}$ small drumlins either side of the 1992 moraine.

\section{$\underline{4.3 \text { Quantities Relating to Statistical Models }}$}

Distribution parameters that can be related to physically-based statistical models of drumlin formation are $\mu_{L}, \sigma_{L}, \alpha, \beta$ and $\lambda$ [Hillier et al., 2016]. The models predict how these parameters will change as the Múlajökull area evolved geomorphologically a time-progression represented by the difference between drumlins outside as compared to inside the 1992 moraine. Although individual changes should be treated with caution where they are not statistically significant, patterns or trends across multiple dimensions (i.e. $H, W, L$ ) might not be coincidental; illustratively, if an observation about $H$ and $W$ both agree with the model but each with a $20 \%$ chance of occurring through random variation (i.e. $P=0.2$ ), then the chance of them both occurring randomly is only $4 \%$ (i.e. $P=0.2 * 0.2=0.04$ ). In Table $1 \alpha$ consistently decreases as drumlins evolve, as does $\beta$ in $H$ and $L$. Unsurprisingly, being a similar quantity (i.e. rate in the statistical models), $\lambda$ follows the same pattern as $\beta$, except there some statistical significance for the increase in $W$ even when considered in isolation. As required, being a very similar 
419 quantity, $\mu_{L}$ behaves as $\mu_{L} L$ increases as drumlins evolve, $W$ decreases and $H$ is apparently

420

421

422

423

424

425

426

427

428

429

430

431

432

433

434

435

436

437

438

439

440

441

442

443

444

445

446

447

448

449

450

451

452

roughly stable. Whilst not readily understandable out of context, these variations invalidate one of the two main physically-based statistical models of drumlin formation [Hillier et al., 2016] (see Section 6.2.3).

4.4 Impact of Relief Quantification Method

Benediktsson et al. [2016] use range to quantify drumlin height, a method that has been called into question [e.g. Smith et al., 2009; Hillier and Smith, 2012; Spagnolo et al., 2012]._To approximately assess the impact of a more sophisticated $H$ computation [e.g. Hillier and Smith, 2012], a correction of $H_{c}=H-(L / 2)^{*} g$ is applied, where $g$ is slope. 0.01 is an approximate central value for the slope of the foreland, which varies between roughly 0.007 and 0.023 [see McCracken et al., 2016]._Slopes of the fitted trends from P1 and P2 are $0.89^{\circ}$ and $0.38^{\circ}$, respectively. The dip direction aligns with drumlin elongation. The lowest point, used in the vertical range quantification, will typically be near the drumlin's distal end, whilst the highest will be somewhat central. Thus, removing the slope between the centre and edge of each drumlin approximates the overestimation of $H$ when range is used [e.g. see Spagnolo et al., 2012]. After applying the correction, the shape of curves equivalent to those in Figure $7 a, d$ is not substantively or visibly different, supporting the idea that using range [Benediktsson et al., 2016] is insufficient to invalidate the conclusions reached here about the scarcity of small drumlins. Indeed, even correcting for more detailed effects, such as applying a different slope either side of the 1992 moraine [McCracken et al., 2016] cannot alter the shape of a size-

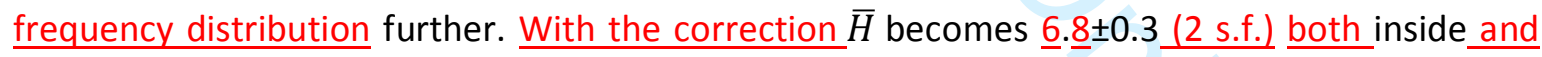
outside the 1992 moraine, with no significant difference $(p=0.942)$. Using a different slope either side of the 1992 moraine, however, may alter mean values (e.g. Section 4.1), even if such complexity in a correction likely exceeds the validity of the approximate assessment used here. To be safe, a full re-computation of $H$ values is recommended in future.

FIG 7 HERE

TABLE 1 HERE

\section{Statistical analysis of UK and Swedish drumlin datasets}


453

454

455

456

457

458

459

460

461

462

463

464

465

To place the observations at Múlajökull in a wider context, the extent to which they are mirrored in other mapping datasets is briefly explored. If data elsewhere are consistent with Múlajökull then conclusions drawn in this paper might apply to other sites globally. Of particular interest are whether under-sampling is sufficient to explain the roll-over at other sites (i.e. UK and Sweden), and how under-sampling might distort statistics. So, Section 5.1 employs a correction for under-sampling to verify the existence of roll-overs, whilst Section 5.2 considers the impact of the correction on $\mu_{L}$ as it is commonly calculated [e.g. Ely et al., 2017] and has implications for understanding the rate at which drumlin height equilibrates with ice conditions (Section 6.2.4).

\subsection{Widespread existence of a roll-over}

The widespread existence of a roll-over is tested by the application of a conservative correction for under-sampling [Hillier et al., 2014], in particular the mean curves on Figure 2._As in Section 4.2 the correction is applied to the exponential model to ascertain if it can be bent downwards sufficiently to explain the roll-over. If the roll-over can be replicated by the correction, then the observation is in some doubt. The correction is likely an illustrative 'worst case' for underdetection because the area is hilly and cluttered (i.e. with trees, woods, houses, infrastructure) and the $5 \mathrm{~m}$ resolution NEXTmap Britain ${ }^{\mathrm{TM}}$ DEM is derived from InSAR observations. Critically, InSAR radar pulses reflect off vegetation, with the returns therefore capturing the top of features such as trees, which must either be statistically removed to estimate a bare earth terrain for mapping [e.g. Sithole and Vosselman, 2004; Clark et al., 2009] or visually compensated for when mapping [e.g. Smith et al., 2006]. This is non-trivial especially, for example, if patches of woodland have greater amplitude and similar spatial scale to drumlins [e.g. Fig 2b of Hillier and Smith, 2012]. The correction curve of Hillier et al. [2014] is used as it is derived from mapping on synthetic DEMs, and thus the only one available that gives absolute values (i.e. not just relative efficacy between mappers) for under-sampling.

The widespread existence of a roll-over is examined first in UK data. UK drumlins [Clark et al., 2009; Spagnolo et al., 2012] are to a first-order approximated by either a log-Normal or a Gamma distribution for $H, W$ and $L$ [e.g. Fig. 1 of Hillier et al., 2016]. Additionally, for large drumlins above modal size, data are approximated by an exponential tail [Hillier et al., 2013]. Correcting for under-sampling is manifestly inadequate to alter this, namely the correction is not sufficient to explain the roll-over and mapping of few small bedforms in terms of $L$ and $W$ 
487 (Figure 8). For $H$ the correction (dashed line) to the exponential model (solid line) appears to be 488 overly pessimistic for drumlins between 5-10 $\mathrm{m}$ in relief, which still fit the exponential trend, 489 and even so cannot explain a relative absence of the smallest forms (Figure 8a). Similar applies 490 for the flow set of 173 drumlins located at a site near Loch Lomond [Hillier and Smith, 2012] 491 (Figure 9). This is both the site at which the correction was created, and demonstrates that the 492 observation also applies to flow-set level datasets. All these studies use the NEXTmap Britain ${ }^{\text {TM }}$ 493 DEM.

494

Secondly, the roll-over is examined in Swedish data. 20,041 drumlins from Sweden mainly conform to roughly log-Normal size distributions in $H, W$ and $L$ (Figure 10), reaffirming previous statistical analysis [supp. mat. in Dowling et al., 2015]. The roll-over occurs at relatively small sizes in these typically ( 94\%) rock-cored forms. Mapping was from LiDAR-based DEMs. Again (see Figure 8a), the under-detection correction may be too conservative, but still cannot entirely account for the roll-overs. A factor of $x 10$ (i.e. $10 \%$ recovery) equates to 2.3 on the vertical (natural) logarithmic scale so that the fraction of drumlins that would need to be missed to eliminate the roll-overs is considerable.

$\underline{\text { In short, whether in the UK or Sweden, using InSAR or LiDAR data, for aggregated or individual }}$ 505 flow sets, for whichever dimension (i.e. $H, W, L$ ), a roll-over exists.

506

507

FIGS 8,9,10 HERE

508

509

$\underline{5.2 \text { Distortions to distribution statistics }}$

510

511 The extent to which distribution statistics are potentially distorted by under-sampling is 512 examined by using five UK flow sets selected in Ely et al. [2017]. This is not intended as a 513 criticism of this particular data set, which has been extensively and carefully quality controlled 514 [e.g. Clark et al., 2009; Spagnolo et al., 2012]. But, this in itself demonstrates the general 515 applicability of any caution needed. The under-sampling correction is applied to the 516 observations so that any impact on distribution shape can be assessed visually (Figure 11). $H$ is 517 selected for plotting as it is most sensitive to the under-sampling correction. The applicability of 518 a log-Normal distribution [Ely et al., 2017] is to a first order a shown to be valid with or without

519 the correction. The curves, however, are altered with the possibility that the statistics might be 520 notably altered. Visually, the concave-up shape on the below $\ln (H)$ of 1 (i.e. $\sim 2.7 \mathrm{~m}$ ) is not 
521 typical of more apparently complete observed distributions (e.g. using LiDAR) or the upper tail

522 of these ones. This is perhaps a qualitative indicator that under-sampling has taken place, and 523 the effect of the correction is more pronounced the lower the mode of the flow-set's size 524 distribution (see dashed box).

525

526 In terms of quantitative assessment the mean of log-transformed data (i.e. $\mu_{\mathrm{L}}$ ) is, illustratively, 527 the statistic focussed upon. It is relatively commonly used, relates to physically-based statistical 528 models, has implications for arguments about rates of equilibrium of drumlins with ice flow 529 (Section 6.2.4), and is intuitively understandable (i.e. location of the distribution). $\mu_{L}$ for $L$ varies 530 by $\pm 0.622(2 \sigma)$ (Table 2 ). This likely reflects a range created by glaciological processes as the 531 mean magnitude of the under-sampling correction is 0.035 or $~ 6 \%$ of this. For $W$ the value is $4 \%$, 532 but rises to $56 \%$ for $H$ with data varying by $\pm 0.465(2 \sigma)$ and a mean correction of 0.258 . Thus, 533 observations of relief might contain materially significant distortions in some cases, perhaps 534 contributing to why a trend in $\mu_{\underline{L}}$ for $H$ predicted by statistical modelling has not been observed [Ely et al., 2017] (Section 6.2.4).

\section{Discussion}

541

\subsection{Are small bedforms produced?}

543

544 The primary purpose of this paper is to rigorously examine the apparent roll-over in drumlin 545 size-distributions and the associated scarcity of small drumlins (i.e. < half modal size), which 546 might be an important signature of subglacial processes. As a purely empirical descriptor of the 547 distribution shape, an exponential distribution fitted above the mode can predict how many 548 small drumlins might naively be expected_[Hillier et al., 2013]. Furthermore, a physically-based 549 statistical model producing exponential distributions can be conceived [Hillier et al., 2016]. It is 550 therefore of interest to determine whether or not under-sampling can explain the existence of 551 the roll-over.

553132 recently and fully emergent drumlins at Múlajökull glacier, Iceland, are shown to exhibit 554 the roll-over (Section 4.2) in highly-accurate LiDAR data in an essentially stable, un-vegetated, 
555 and non-anthropogenically influenced till plain where post-glacial degradation is minimal (Section 3). Mapping in GIS follows best practice, is ground-truthed, and details in the methods 557 of quantification of the morphometrics (e.g. $H$ ) are shown to be insufficient to alter this

558 conclusion (Section 4.4). Moreover, even applying a conservative correction for under-sampling 559 during manual mapping is equally insufficient to invalidate the result (Section 4.3). Some doubt 560 might exist as a conservative mapping method was used [Benediktsson et al., 2016; Dowling,

561 2016], requiring each drumlin to be elevated above its surroundings on all sides. This could miss 562 subtle drumlins that are low relief, but wide and long, because if they are on a gentle larger563 scale (i.e. 'regional' [see Hillier and Smith, 2008]) slope then the up-dip face of the drumlin may only be shallower and never actually slope downward. However, this situation is scale-invariant, 565 566 reflecting only shape and not scale. Thus, such omissions could be argued to reduce the number of small forms found only if small drumlins are also typically flatter; however, there is no evidence that $H / W$ decreases with $W$ either inside or outside the 1992 moraine (i.e. $r^{2}<0.1$ ). Two other elements of the data presented here also point to a relative scarcity of small 569 drumlins. Firstly, the dominant topographic variations in profiles across the LiDAR DEM viewed 570 at high vertical exaggeration (i.e. x32, inset panels in Figure 5) are at the horizontal scale of 571 drumlins (i.e. $~ 100 \mathrm{~m}$ ), without a significant high-amplitude contribution from variations 572 between this scale and $10 \mathrm{~m}$. Namely, there is no evidence of a progression from the mapped drumlins towards many increasingly small drumlin-like forms. Certainly where 10 times the amount that are currently mapped might originate from in order to eliminate the roll-over. Secondly, the mapping [i.e. Benediktsson et al., 2016] suggests that many small drumlins are not going to be revealed by draining the lake-filled interfluves inside the 1992 moraine; this is simply because small drumlins have not been revealed in these locations outside the 1992 moraine. Thus, in summary, at Múlajökull where observational ambiguity is eliminated or minimized, the roll-over is not to be due to i) source data via DEM resolution or quality, ii) 'detectability' or mapper ability in complex (i.e. anthropogenically cluttered or vegetated) landscapes, iii) quantification method to determine morphometrics (e.g. H), or iv) post-glacial degradation. In other words, with preservation and observation accounted for it is possible to clearly state that if small drumlins are created then few survive to pass outside the ice margin. In this sense, they are not 'produced' by the glacier for preservation in 586

587 It is also possible to comment on the earlier-stage, subglacial production of small drumlins. 588 Without sub-ice evidence, it could be possible that drumlins originated significantly further up- 
589 stream under the ice and always grew, merged, or were destroyed before being exposed, 590 thereby not ultimately being preserved in the geomorphological record. GPR data preclude this 591 for Múlajökull [Lamsters et al., 2016]. In common with the LiDAR of the forefield (Figure 5), 592 dominant topographic variations in the near-margin basal sub-ice topography are at the scale 593 of the streamlined ridges that are being interpreted as drumlins (see Figs. 2a \& 3 of Lamsters et 594 al. [2016]). Namely, there is no evidence of many small drumlins. With respective horizontal 595 and vertical accuracies of $<1 \mathrm{~m}$ and $12 \mathrm{~m}$ in these GPR data, possible drumlins well within the 596 roll-over (e.g. $W \sim 40 \mathrm{~m}$ ) would be detectable if they existed. At Múlajökull, at least, it is 597 therefore not any ice-sediment interaction that occurs during a passage out from under the ice 598 [e.g. Benediktsson et al., 2016; Lamsters et al., 2016] that eliminates small drumlins and causes 599 their scarcity.

600

601 Finally, Múlajökull [Johnson et al., 2010; Benediktsson et al., 2016; McCracken et al., 2016] 602 provides insights into whether or not many small drumlins ever existed. Everywhere at 603 Múlajökull, including under current ice, small drumlins are scarce. Thus, if any of the three 604 zones (i.e. 'inside', 'outside', currently subglacial) can be argued to reflect the earliest stages of 605 drumlin formation, drumlins must have formed by streamlining pre-existing landforms rather 606 than through progressive growth from small to full-size features. Sedimentology and 607 stratigraphy have been used to create an understanding of the spatial distribution of the 608 cumulative intensity of geomorphic work done by surge-cycles at Múlajökull [Johnson et al., 609 2010; Benediktsson et al., 2016; McCracken et al., 2016]; specifically, the ice-proximal area 610 inside the 1992 moraine is argued to have experienced more surges, more geomorphological 611 work, and it contains more evolved and elongate (i.e. mean $L / W$ ratio of 3.0) drumlins, than the 612 distal area outside it (mean $L / W=1.9$ ). Also, at Múlajökull the influence of a number of other factors that could affect drumlin morphology (e.g. bedrock, till variation, large-scale topography) is likely minimal. Thus, since the Múlajökull drumlins have demonstrably elongated in surges, and yet the distal ones have not elongated much (i.e. $L / W<2.0$ ), it is possible to argue that the distal drumlins are comparatively geomorphologically 'immature' and represent an early stage of drumlin formation. As such, observing few small drumlins in the till plain outside the 1992 moraine strongly implies that few were produced or existed in the earlier stages of drumlin genesis. A first explanation for the scarcity of small drumlins in apparently immature zones (e.g. elongation ratio $\$ 2.0$ ), at least at sites similar to Múlajökull (i.e. lobes with near-margin drumlin genesis), is that drumlins form by streamlining pre-existing landforms (e.g. moraines, debris fans) rather than through progressive growth from small to full-size 
623 features.A second explanation is that small bedforms grew and/or merged rapidly before

624

625

626

627

628

629

630

631

632

633

634

635

636

637

638

639

640

641

642

643

644

645

646

647

648

649

650

651

652

653

654

655

656 significant streamlining had occurred. In terms of all $H, L$ and $W$ small drumlins are scarce even in the apparently immature area outside the 1992 moraine [Benediktsson et al., 2016], which has low elongation ratios (i.e. <2.0), so if they once existed they must have disappeared by this stage. A third, and our preferred, explanation is that drumlins at Múlajökull initiate as relatively broad and shallow features that increase in amplitude notably faster than they elongate, and grow and/or merge rapidly before significant streamlining has occurred. In addition to the other constraints (e.g. such as mean sizes $\mu_{L}$ in Section 6.2.1), this is supported by an interpretation of the spread of size-frequency observations (i.e. $\sigma_{L}$ ) in the context of statistical modelling that give insights into rates of change (see Section 6.2.3). In the later two explanations, regularity could emerge through the aspects of the process of growth (e.g. stochasticity) rather than reflecting initial conditions [see Hillier et al., 2016]. In the first explanation, pre-existing features with some regularity in spacing, are required to conform with this tendency in drumlins [Clark et al., 2018].

Away from Múlajökull, the complication exists that drumlin fields are produced substantially away from an ice margin. Thus, the possibility exists for sub-ice modification or destruction of any small drumlins produced before they emerge. Additional sub-ice evidence (e.g. GPR) is needed to constrain this possibility further. Seismic [King et al., 2007] and radar [King et al., 2009] data collected in Antarctica are of a different character and lower horizontal resolution $(\sim 50 \mathrm{~m})$ than LiDAR, and of mega-scale glacial lineations (MSGL), but it is interesting that they are reported as visually indistinguishable from relict bedforms of the Dubawnt palaeo-ice stream bed captured in Landsat images. The Dubawnt flow set lacks the many small bedforms expected of the exponential extrapolation_[Hillier et al., 2013; Stokes et al., 2013a], and combining this with the Antarctic geophysics gives a first tentative indicator of potential scarcity under ice streams. A final possibility, that is difficult to constrain, is that Múlajökull's foreland may simply represent an atypical phase of drumlin field evolution where small drumlins are under-represented.

Observational certainty is higher for forms that are currently exposed. A compilation of various datasets from the UK and Sweden [Clark et al., 2009; Hillier and Smith, 2012; Spagnolo et al., 2012; Dowling et al., 2015; Ely et al., 2017] in Section 5 demonstrates that the roll-over exists for data from varied locations, with varied data sources, and for both aggregated data and that at the level of individual flow sets, which potentially represent glaciological conditions in a 
657 single place and time. Predominantly, this is valid even with a correction for under-detection 658 applied_Section 5). Thus, behaviours similar to that at Múlajökull (i.e. whatever leads to few 659 small forms) may be more widespread than just that site. The roll-over is least apparent in rock660 cored drumlins recorded in LiDAR data [i.e. Dowling et al., 2015] where, in contrast to other 661 data, a log-Normal distribution does not well explain the very largest forms and a Gamma 662 distribution is visibly less adequate (Figure 10). It therefore remains entirely possible that the 663 balance of physical processes that dictate bedform sizes changes along a spectrum from hard664 665 667

668 With the robustness of the size-frequency data at Múlajökull established_(Sections 4 \& 5), they 669 can be taken as a firm constraint upon drumlin formation models (i.e. statistical, conceptual, or 670 numerical ice flow) intended to apply at this site. It is open to debate how representative the 671 Múlajökull site is, but it must be incorporated for a theory to have general applicability, and so 672 the implications of the statistical size analysis are discussed below with this taken as read. 673 The current conceptual model for Múlajökull [Benediktsson et al., 2016; McCracken et al., 2016] is considered first (Section 6.2.1). After this only the 132 currently exposed drumlins are considered $\mathrm{as}_{L}$ at present, they are the observations that most reliably isolate the evolution of bedforms through time with other conditions held constant_(see Section 2). Early, protodrumlin morphology is noted in Section 6.2.2, with implications for the initiation of any numerical or statistical model. Then the applicability or otherwise of statistical models to the Múlajökull site is evaluated, constraining which remain tenable. Finally ${ }_{2}$ rates at which the dimensions (i.e. $H, W$, or $L$ ) equilibrate is considered, contributing to our overview of how 683 684 685

686 The current conceptual model of [Johnson et al., 2010; Benediktsson et al., 2016; McCracken et 687 al., 2016] (see Section 2) is based on sedimentary and stratigraphic observations ${ }_{2}$ and the 688 689 but the increase in $L$ with exposure to more surges (i.e. inside the 1992 moraine), decrease in $W$ reported mean changes in $H, W$ and $L$ at Múlajökull. Thus, it cannot be tested by these changes, 690 and probable invariance in $H$ are all verified statistically (Table 1, Section 4 ). Namely, the model 
691 is not based on a falsely confident misinterpretation of summary statistics from small samples

692 of data in the foreland.

693

694 The five drumlins measured under Múlajökull by Lamsters et al. [2016] tentatively suggest that

695 the trends observed in the foreland do not continue beneath the glacier; they are higher and 696 wider rather than narrow and of similar height as simple extrapolation would suggest. Without

697 detailed explanation this was attributed to either i) more till layers, ii) more sediment due to

698 unspecified ice-stress differences, or iii) variation in till composition (e.g. stiffer till more

699 resistant to erosion). A smoother transition appears to exist between the swales and crests of

700 the current subglacial drumlins than on the foreland. Without yet being subject to being

701 interspersed by proglacial lakes and their associated sedimentation, these subglacial drumlins

702 lack clear breaks in slope at their margins, and thus the former glacier bed is likely not directly

703 comparable to its foreland [e.g. Finlayson, 2013]. Some metrics (e.g. inter-crest spacing) appear

704 little affected and similar to the exposed drumlins, whilst $H \underline{\text { in particular is more sensitive. It is }}$

705 clear, however, that the model of Múlajökull cannot ultimately only be based on data from the

706 foreland.

707

708 6. 2.2 .2 Initial conditions for numerical and statistical modelling

709

710 Observations at Múlajökull imply that drumlins may not initiate as perturbations that are very 711 small in all dimensions (i.e. $H, L, W$ ), a simplifying assumption commonly used in both numerical 712 ice-flow [e.g. Hindmarsh, 1998; Dunlop et al., 2008; Chapwanya et al., 2011] and statistical 713 [Fowler et al., 2013; Hillier et al., 2016] modelling. The current model for Múlajökull [Johnson et 714 al., 2010; Benediktsson et al., 2016; McCracken et al., 2016; Iverson et al., 2017] postulates that 715 drumlins initiate as wide, rounded and relatively low amplitude topographic features (i.e. $\underline{H}$ is 716 small but $L$ and $W$ are not), and the inferences from the size-frequency observations at 717 Múlajökull in the context of the Stochastic Instability statistical model are consistent with this 718 (see Section 6.2.3). Exploring fully the implications of this initial condition used in models is 719 outside of the scope of this paper, so it is simply noted that future modelling should consider 720 the sensitivity of outputs to the initial size distribution selected for the modelling [e.g. see 721 Hillier et al., 2016].

722

723 ㅁ. $6.2 . \underline{3}$ Statistical models

724 
As a step to bridging the gap between geomorphological form and process Hillier et al. [2013] proposed a conceptual model to explain the size-distributions of subglacial bedforms in terms of stochastic ice-sediment-water interaction. This has led to a variety of physically-based statistical models being developed to formalize the postulated stochastic behaviour [Fowler et al., 2013; Hillier et al., 2016]. The statistical models include various elements (e.g. initial size distribution, growth rate law) and predict size-frequency distributions and how they evolve through time as the drumlins evolve. In making specific predictions about observable quantities (e.g. $\left.\mu_{L}\right)$, they are testable and falsifiable.

A statistical model based on waiting time (i.e. Poisson) randomness and a single episode of drumlin building that might be a surge ${ }_{\perp}$ can produce an exponential size-frequency distribution. Illustratively, this is model M8 of Hillier et al. [2016]. However, a securely evidenced roll-over at Múlajökull (Section 4.2) and more widely (Section 5) now firmly precludes any statistical model that produces an exponential size-frequency distribution from being a viable model. Two statistical models that include randomness through time in drumlin growth ${ }_{2}$ and are based on glaciologically plausible physical conditions, can explain size-frequency distributions with a rollover, but these are difficult to distinguish in aggregated UK data [Hillier et al., 2016]. A powerful aspect of the Múlajökull site is that it contains a progression from less evolved drumlins outside the 1992 moraine to more evolved ones inside, effectively two snapshots of drumlin growth at two different times. This constraint allows tests of predictions of how subglacial bedforms (e.g. drumlins) progressively evolve with time, which gives more potential to distinguish between models.

The first physically-based statistical model that can explain a roll-over is the Waiting Time (WT) model_[Hillier et al., 2016]. The WT model is based on Poisson randomness and creates a Gamma distribution with two parameters (i.e. $\alpha, \beta$ ). $\beta$ is the rate at which conditions in the ice-sediment-water switch between those suitable for growth and those that cause bedforms to shrink, and is expected to remain constant through time in the WT model as constructed. No change in $\beta$ with time for $H$ and $W$ at Múlajökull is therefore in agreement with the $W T$ model, but the statistically significant decrease for $L$ is difficult to reconcile with the model. $\alpha$ reflects the number of growth episodes (e.g. surges) experienced on average by the bedforms, and so is expected to grow with time. Thus, a tendency to decrease in $H$ and $W$ even through not statistically significant, especially combined with the statistically significant decrease in $\alpha$ for $L$, produces an observation that is inconsistent with the $W T$ model. The $W T$ model as currently 
759

760

761

762

763

764

765

766

767

768

769

770

771

772

773

774

775

776

777

778

779

780

781

782

783

784

785

786

787

788

789

790

791

792

constructed is therefore falsified, although it is worth emphasizing that as with mathematical models of drumlin formation [e.g. Hindmarsh, 1998; Chapwanya et al., 2011; Hooke and Medford, 2013; Iverson et al., 2017] variants that remedy this might be constructible.

The second physically-based statistical model that can explain a roll-over is the Stochastic Instability (SI) model created by Fowler et al. [2013]_and re-formulated and generalized by Hillier et al. [2016]. The SI model creates log-Normal distributions with two parameters (i.e. $\mu_{L}$, $\left.\sigma_{L}\right) . \mu_{L}$ has already been interpreted at Múlajökull in terms of the state of the drumlin sizes at two times (Section 6.2.1), but $\sigma_{L}$ can offer additional information on the rate of changes at the two times. $\sigma_{L}$ for $H$ is greater than that for $W$ or $L$ implying that growth rate $(k)$ is fastest in this dimension both inside and outside the 1992 moraine_[see Eq. 27 of Hillier et al., 2016], in agreement with aggregated UK data_[Hillier et al., 2016]. Outside the 1992 moraine, where fewest surges have sculpted the morphology, $\sigma_{L}$ values imply $k_{W}$ exceeds $k_{L}$. At face value, this implies that drumlins outside the 1992 moraine are getting less elongate with time. Alternatively, it can be interpreted as being consistent with $W$ values not initially starting small as assumed in the $S I$ model, within which the only way to become wide is to grow to be wide. This second interpretations is much easier to reconcile with the Múlajökull site (see Section 2). Inside the 1992 moraine $\sigma_{L}$ values imply $k_{L}$ exceeds $k_{W}$ as for the UK data [i.e. of Clark et al., 2009], indicating that drumlins have elongated with time. Observations in the two zones can be $\underline{\text { reconciled if drumlins elongate with time, but with streamlining taking a little time to become }}$ dominant as the signal of the initial conditions (i.e. broad gentle proto-drumlins) is progressively over-printed. This is entirely consistent with suggestions in Hillier et al. [2016] that different dimensions might behave differently (i.e. $L$ continuing to grow after $W$ is restricted)._Overall, the observations do not falsify the $S I$ model, indeed the most logical interpretation of the size-frequency data places it into agreement with initial conditions recently postulated in mathematical model for drumlin formation at Múlajökull [e.g. Johnson et al., 2010; Iverson et al., 2017]. Thus, it is clear that statistical models will have greater explanatory power if used in conjunction with site-specific conceptual or mathematical models.

\subsection{Equilibration with flow conditions}

Ely et al. [2017] speculatively interpret a lack of trend in $\mu_{L}$ and $\sigma_{L}$ for $H$ in UK flow sets as rapid stabilisation, consistent with inferences by Hillier et al. [2016] using aggregated UK size data that $H$ grows and evolves relatively more rapidly that $W$ or $L$. The other likely explanation for an 
793

794

795

796

797

798

799

800

801

802

803

804

805

806

807

808

809

810

811

812

813

814

815

816

817

818

819

820

821

822

823

824

825

826

absence of a trend in the data of Ely et al. [2017], which cannot yet be excluded (Section 5.2), is observational uncertainty in $H$ (e.g. due to under-detection or the measurement technique used); i.e. a trend might still be present, just masked by noise. However, the lack of a distinguishable change in $H$ between two areas either side of the 1992 moraine at Múlajökull that have experienced similar glacial conditions but a different number of surges adds weight from a better constrained site to the view that $H$ stabilises rapidly. Specifically, stabilisation here is refined to mean that $H$ has finished increasing or decreasing, does this rapidly with respect to $L$ or $W$, and perhaps implies equilibrating with ice-flow conditions. In this context rapid must mean short compared to the $\sim 400-800$ year LIA time frame available at Múlajökull indicated by formation of the Arnarfellsmúlar terminal moraine. This adjustment might even be on the decadal timescale [e.g. Hillier et al., 2016], based on geophysical evidence [e.g. Smith et al., 2007], sediment flux [Rose, 1989] and geometrical arguments [Goldstein, 1994; Dowling et al., 2016]. Stabilising $H$ in the absence of a sharp spike in observational frequency at a postulated capping height requires any upper limit on dimensions to be 'fuzzy' or probabilistic [Hillier et al., 2016].

\section{Conclusions}

From statistical analysis of 143 newly emergent drumlins, recently created by the Múlajökull glacier, in conjunction with on the order of 100,000 drumlins mapped in the UK and Sweden, the following main conclusions can be drawn.

- Few small drumlins are produced in the active Múlajökull drumlin field.

- Our preferred explanation for the scarcity of small drumlins at Múlajökull is that drumlins form stochastically, during surge_cycles, by wide and gentle pre-existing $\underline{\text { undulations }} \underline{\text { rapidly increasing in amplitude before significant streamlining occurs. The }}$ scarcity of small drumlins in the less evolved (i.e. 'immature') zone outside the 1992 moraine requires the rapidity, whilst size-frequency observations (i.e. $\mu_{L}, \sigma_{L} L$ in the context of statistical modelling give insights into rates of growth and imply the protodrumlin morphology.

- In the UK and Sweden, and in a variety of data types, size-frequency distributions have a 'roll-over' similar to that at Múlajökull, providing wider evidence that few small drumlins exist in previously glaciated landscapes. Thus, behaviours similar to that at Múlajökull may be more widespread than just that site. 
828 It is also interesting to note that the first-order properties (i.e. approximately log-Normal 829 shape) of size-frequency distributions is likely not altered substantially by under-sampling, 830 although most care is needed for relief (i.e. height). Size-frequency distributions for $H$ remain 831 most sensitive to under-detection, and might still have materially significant distortions in some 832 cases, which should be accounted for when interpreting data or derived statistics. Finally, it 833 seems clear that statistical models are useful companions to their numerical ice-flow 834 counterparts as tools to assist our understanding of ice-base processes, especially if placed into 835 a site-specific context. For example, a mathematical model focused on physical behaviours at 836 Múlajökull [e.g. Johnson et al., 2010; Iverson et al., 2017] might be blended with statistical 837 modelling (i.e. Stochastic Instability model) [Hillier et al., 2016]. With a statistical model ground838 truthed at a site, the modelling could be used to extrapolate and thereby be tested for consistency with observations across Earth. In particular, observations at Múlajökull add weight to a model previously posited for testing by Hillier et al. [2016] in which $H$ evolves relatively rapidly [Hillier et al., 2016]_to be at equilibrium with ice-sediment-water conditions_[Ely et al., 2017], W changes more slowly constrained geometrically by interactions with neighbouring bedforms_[e.g. Hillier et al., 2013, 2016; Clark et al., 2018], but L is free to grow. Thus, statistically enhanced modelling could feed into the longstanding debate on a subglacial bedform continuum [e.g. Aario, 1977; Rose, 1987] and be a step towards using drumlin fields as proxies for the critical parameters used in ice sheet reconstructions and modelling.

\section{Acknowledgements}

852

853 We thank the organisers of the 'Beauty of Drumlins' symposium for bringing the authors 854 together in Lund, Sweden, May 2017, in honour of Professor Per Möller upon his retirement. 855 We are grateful to Chris Stokes and an anonymous reviewer for their insightful comments, 856 which improved the manuscript. 
860

861

862

863

864

865

866

867

868

869

870

871

872

873

874

875

876

877

878

879

880

881

882

883

884

885

886

887

888

889

890

891

892

893

894

895

896

897

898

\section{Bibliography}

Aario, R. (1977), Classification and terminology of moranic landforms in Finland, Boreas, 6(2), 77-100.

Ardelean, F., L. Drăguţ, P. Urdea, and M. Török-Oance (2013), Variations in landform definition: a quantitative assessment of differences between five maps of glacial cirques in the Jarcu Mountains (Southern Carpathians, Romania), Area, 45, 348-357, doi:10.1111/area.12043.

Benediktsson, Í. Ö., A. Schomacker, M. D. Johnson, Ó. Ingólfsson, A. J. Greiger, and E. R. Guðmundsdóttir (2015), Architecture and structural evolution of an early Little Ice Age terminal moraine at Múlajökull, surge-type glacier, Iceland, J. Geophys. Res., 120, doi:10.1002/2015JF003514.

Benediktsson, Í. Ö., S. A. Jónsson, A. Schomacker, M. D. Johnson, Ó. Ingólfsson, L. Zoet, N. R. Iverson, and J. Stotter (2016), Progressive formation of modern drumlins at Múlajökull, Iceland: stratigraphical and morphological evidence, Boreas, 45, 567-583, doi:10.1111/bor.12195.

Benn, D. I., and D. J. A. Evans (2010), Glaciers and Glaciation, 2nd ed., Hodder, Oxford, UK.

Björnsson, H. (1986), Surface and bedrock topography of ice caps in Iceland, mapped by radio echo- sounding, Ann. Glaciol., 8, 11-18.

Björnsson, H. (2009), Jöklar á Íslandi [with English summary], Forlagiđ, Reykjavík.

Björnsson, H., and F. Pálsson (2008), Icelandic glaciers, Jökul, 58, 365-386.

Björnsson, H., F. Pálsson, O. Sigurdsson, and G. Flowers (2003), Surges of glaciers in Iceland, Ann. Glaciol., 36, 82-90.

Bohnensteihl, D. R., J. K. Howell, and R. N. Hey (2008), Distribution of axial lava domes along a superfast overlapping spreading center, 27-32S on the East Pacific Rise, G3, 9(12), doi:10.1029/2008GC002158.

Boulton, G. (1987), A theory of drumlin formation by subglacial sediment deformation, in Drumlin Symposium, edited by J. K. Menzies and J. Rose, pp. 25-80, Balkema, Rotterdam.

Boulton, G., and R. C. A. Hindmarsh (1987), Sediment deformation beneath glaciers - rheology and geological consequences, J. Geophys. Res. Earth Planets, 92(B9), 9059-9082.

Ten Brink, U. (2006), Size distribution of submarine landslides and its implications for tsunami hazard in Puerto Rico, Geophys. Res. Lett., 33, L11307, doi:10.1029/2006GL026125.

Chapwanya, M., C. D. Clark, and A. C. Fowler (2011), Numerical computations of a theoretical model of ribbed moraine formation, Earth Surf. Proc. Land., 36, 1105-1112.

Chorley, R. J. (1959), The Shape of drumlins, J. Glaciol., 3, 339-344.

Clark, C. D. (1993), Mega-scale glacial lineations and cross-cutting ice-flow landforms, Earth Surf. Process. Landforms, 18(1), 1-29.

Clark, C. D., A. L. C. Hughes, S. L. Greenwood, M. Spagnolo, and F. S. L. Ng (2009), Size and shape characteristics of drumlins, derived from a large sample, and associated scaling laws, Quat. Sci. Rev., 28(7-8), 677-692, doi:10.1016/j.quascirev.2008.08.035. 
899

900

901

902

903

904

905

906

907

908

909

910

911

912

913

914

915

916

917

918

919

920

921

922

923

924

925

926

927

928

929

930

931

932

933

934

935

936

937

938

939
Clark, C. D., J. C. Ely, M. Spagnolo, U. Hahn, A. Hughes, and C. R. Stokes (2018), Spatial orgainzation of drumlins, Earth Surf. Proc. Land., 43, 499-513, doi:10.1002/esp.4192.

Van Coillie, F. M. B., S. Gardin, F. Anseel, W. Duyck, L. P. C. Verbeke, and R. R. De Wulf (2014), Variability of operator performance in remote-sensing image interpretation: the importance of human and external factors, Int. J. Remote Sens., 35, 754-778, doi:10.1080/01431161.2013.873152.

Colgan, P., and D. M. Mickelson (1997), Genesis of streamlined landforms and flow history of the Green Bay Lobe, Wisconsin, USA, Sediment. Geol., 111, 7-25.

Dowling, T. P. F. (2016), The drumlin problem: Streamlined subglacial bedforms in southern Sweden, LUNDQUA Thesis, 80, 175.

Dowling, T. P. F., M. Spagnolo, and P. Moller (2015), Morphometry and core type of streamlined bedforms in southern Sweden from high resolution LiDAR, Geomorphology, 236, 54-63, doi:10.1016/j.geomorph.2015.02.018.

Dowling, T. P. F., P. Moller, and M. Spagnolo (2016), Rapid subglacial streamlined bedform formation at a calving bay margin, J. Quat. Sci., 31(8), 879-892.

Dunlop, P., C. D. Clark, and R. C. A. Hindmarsh (2008), Bed Ribbing Instability Explanation: Testing a numerical model of ribbed moraine formation arising from coupled flow of ice and subglacial sediment, J. Geophys. Res., 113(F3), F03005, doi:10.1029/2007JF000954.

Ely, J. C., C. D. Clark, M. Spagnolo, A. L. C. Hughes, and C. R. Stokes (2017), Using the size and position of drumlins to understand how they grow, interact and evolve, Earth Surf. Proc. Land., doi:10.1002/esp.4241.

Evans, D. J. A., and D. R. Twigg (2002), The active temperate glacial landsystem: a model based on Breiðamerkujökull and Fjallsjökull, Iceland, Quart. Sci. Rev., 21, 2143-2177, doi:10.1016/S0277-3791(02)00019-7.

Evans, D. J. A., S. Livingstone, A. Vieli, and C. Ó Cofaigh (2009), The palaeoglaciology of the central sector of the British and Irish Ice Sheet: reconciling glacial geomorphology and preliminary ice sheet modelling, Quat. Sci. Rev., 28, 739-757.

Favey, E., A. Geiger, G. . H. Guðmundsson, and A. Wehr (1999), Evaluating the potential of an airborne laser-scanning system for measuring volume changes of glaciers, Geogr. Ann. A, $81(4), 555-561$.

Finlayson, A. (2013), Digitial surface models are not always representative of former glacier beds: Palaeoglaciological and geomorphological implications, Geomorphology, 194, 25-33.

Fowler, A. C. (2000), An instability mechanism for drumlin formation, in Deformation of Glacial Materials, edited by A. J. Maltman, B. Hubbard, and M. J. Hambrey, pp. 307-319, Geol. Soc. Publishing House, London.

Fowler, A. C., M. Spagnolo, C. D. Clark, C. R. Stokes, A. L. C. Hughes, and P. Dunlop (2013), On the size and shape of drumlins, Int. J. Geomath, 4, 155-165, doi:10.1007/s13137-0130050-0.

Frattini, P., and G. B. Crosta (2013), The role of material properties and landscape morphology on landslide size distributions, Earth Planet. Sci. Lett., 361, 310-319, doi:10.1016/j.epsl.2012.10.029.

URL: http://mc.manuscriptcentral.com/sgff Email: Christian.Skovsted@nrm.se 
940

941

942

943

944

945

946

947

948

949

950

951

952

953

954

955

956

957

958

959

960

961

962

963

964

965

966

967

968

969

970

971

972

973

974

975

976

977

978

979

Gardin, S., S. M. J. van Laere, F. M. B. van Coillie, F. Anseel, W. Duyck, R. R. de Wulf, and L. P. C. Verbeke (2011), Remote sensing meets psychology: a concept for operator performance assessment., Remote Sens. Lett., 2, 251-257, doi:10.1080/01431161.2010.516280.

Goldstein, B. (1994), Drumlins of the Puget Lowland, Washington state, USA, Sediment. Geol., 91, 299-311.

Haselton, G. M. (1966), Glacial geology of Muir Inlet, southeast Alaska, Ohio State University Institute of Polar Studies Report 18, 18pp.

Hättestrand, C., S. Gotz, J. O. Näslund, D. Fabel, and A. P. Stroeven (2004), Drumlin formation time: Evidence from northern and central Sweden, Geogr. Ann. Ser. A-Physical Geogr., 86A(2), 155-167.

Hillier, J. K., and M. Smith (2008), Residual relief separation: digital elevation model enhancement for geomorphological mapping, Earth Surf. Process. Landforms, 33(14), 2266-2276, doi:10.1002/esp.

Hillier, J. K., and M. Smith (2012), Testing 3D landform quantification methods with synthetic drumlins in a real DEM, Geomorphology, 153, 61-73, doi:10.1016/j.geomorph.2012.02.009.

Hillier, J. K., and M. J. Smith (2014), Testing techniques to quantify drumlin height and volume; synthetic DEMs as a diagnostic tool, Earth Surf. Proc. and Landforms, 39(6), 676-688, doi:10.1002/esp.3530.

Hillier, J. K., and A. B. Watts (2007), Global distribution of seamounts from ship-track bathymetry data, Geophys. Res. Lett., 34(13), doi:10.1029/2007GL029874.

Hillier, J. K., M. J. Smith, C. D. Clark, C. R. Stokes, and M. Spagnolo (2013), Subglacial bedforms reveal an exponential size-frequency distribution, Geomorphology, 190, 82-91, doi:10.1016/j.geomorph.2013.02.017.

Hillier, J. K. et al. (2014), Manual mapping of drumlins in synthetic landscapes to assess operator effectiveness, J. Maps, 11(5), 719-729, doi:10.1080/17445647.2014.957251.

Hillier, J. K., I. A. Kougioumtzoglou, C. R. Stokes, M. J. Smith, and C. D. Clark (2016), Exploring explanations of subglacial bedform sizes using statistical models, PlosONE, 11(7), e0159489, doi:10.1371/journal.pone.0159489.

Hindmarsh, R. C. A. (1998), Drumlinization and drumlin-forming instabilities: viscous till mechanisms, J. Glaciol., 44(147), 293-314.

Hollingsworth, S. E. (1931), The glaciation of western Edenside and adjoining areas and the drumlins of Edenside and the Solway basin, Quart. J. Geol. Soc. London, 87(2), 281-359.

Hooke, R., and A. Medford (2013), Are drumlins a product of thermo-mechanical instability?, Quat. Res., doi:10.1016/j.yqres.2012.12.002.

Iverson, N. R., R. G. McCracken, L. Zoet, Í. Ö. Benediktsson, A. Shomacker, M. D. Johnson, and J. Woodard (2017), A theoretical model of drumlin formation based on observations at Múlajökull, Iceland, J. Geophys. Res., 122, doi:10.1002/2017JF004354.

Jóhannesson, T., H. Björnsson, E. Magnússon, S. Guðmundsson, F. Pálsson, O. Sigurđsson, T. Thorsteinsson, and E. Berthier (2014), Ice-volume changes, bias estimation of massbalance measurements and changes in subglacial lakes derived by lidar mapping of the 
1001

1002

1003

1004

1005

1006

1007

1008

1009

1010

1011

1012

1013

1014

1015

1016

1017

1018

1019

surface of Icelandic glaciers, Ann. Glaciol., 54(63), 63-74, doi:10.3189/2013AoG63A422.

Johnson, M. D., A. Schomacker, Í. Ö. Benediktsson, A. J. Geiger, A. Ferguson, and Ó. Ingólfsson (2010), Active drumlin field revealed at the margin of Múlajökull , Iceland: A surge-type glacier, Geology, 38(10), 943-946, doi:10.1130/G31371.1.

Jónsson, S. A., A. Schomacker, Í. Ö. Benediktsson, Ó. Ingólfsson, and M. D. Johnson (2014), The drumlin field and the geomorphology of the Múlajökull surge-type glacier, central Iceland, Geomorphology, 207, 213-220.

Jorge, M. G., and T. Brennand (2017), Measuring (subglacial) bedform orientation, length, and longitudinal asymmetry - Method assessment, PlosONE, 12(3), doi:10.1371/journal.pone.0174312.

King, E. C., J. Woodward, and A. M. Smith (2007), Seismic and radar observations of subglacial bed forms beneath the onset zone of Rutford Ice Stream Antarctica, J. Glaciol., 53(183), 665-672.

King, E. C., R. C. A. Hindmarsh, and C. R. Stokes (2009), Formation of mega-scale glacial lineations observed beneath a west Antarctic ice stream, Nat. Geosci., 2, 585-596.

Korsgaard, N., A. Schomacker, Í. Ö. Benediktsson, N. K. Larsen, Ó. Ingólfsson, and K. H. Kjær (2015), Spatial distribution of erosion and deposition during a glacier surge: Brúarjökull, Iceland, Geomorphology, 250, 258-270.

Krüger, J. (1987), Relation of drumlin shape and distribution to drumlin stratigraphy and glacial history, Mýrdalsjökull, Iceland., in Drumlin Symposium, edited by J. Menzies and J. Rose, pp. 257-266, Balkema, Rotterdam.

Lamsters, K., J. Karuss, A. Recs, and D. Berzins (2016), Detailed subglacial topography and drumlins at the marginal zone of Múlajökull outlet glacier, central Iceland: Evidence from low frequency GPR data, Polar Sci., 10, 470-475.

Livingstone, S., C. Ó Cofaigh, and D. J. A. Evans (2008), Glacial geomorphology of the central sector of the last British-Irish Ice Sheet, J. Maps, 358-377, doi:10.4113/jom.2008.1032.

MacLachlan, J. C., and C. Eyles (2013), Quantitative geomorphological analysis of drumlins in the Peterborough drumlin field, Ontario, Canada, Geogr. Ann. Ser. A, Phys. Geogr., 95(2), 125-144.

Malamud, B. D., D. L. Turcotte, F. Guzzetti, and P. Reichenbach (2004), Landslide inventories and their statistical properties, Earth Surf. Proc. and Landforms, 29, 687-711, doi:10.1002/esp.1064.

McCracken, R. G., N. R. Iverson, Í. Ö. Benediktsson, A. Scomacker, L. Zoet, M. D. Johnson, T. S. Hooyer, and Ó. Ingólfsson (2016), Origin of the active drumlin field at Múlajökull, Iceland: New insights from till shear and consolidation patterns, Quart. Sci. Rev., 148, 243-260.

van der Meer, J. J. M. (1983), A recent drumlin with fluted surface in the Swiss Alps, in Tills and Related Deposits, edited by C. Schluchter and J. Rabassa, pp. 105-110.

Menzies, J. (1979), A review of the literature on the formation and location of drumlins, Earth Sci. Rev., 14, 315-59.

Ó Cofaigh, C., J. A. Dowdeswell, E. C. King, J. B. Anderson, C. D. Clark, D. J. A. Evans, J. Evans, R. C. 
1020

1021

1022

1023

1024

1025

1026

1027

1028

1029

1030

1031

1032

1033

1034

1035

1036

1037

1038

1039

1040

1041

1042

1043

1044

1045

1046

1047

1048

1049

1050

1051

1052

1053

1054

1055

1056

1057

1058

1059

A. Hindmarsh, R. D. Larter, and C. R. Stokes (2010), Comment on Shaw J., Pugin, A. and Young, R. (2008): "A meltwater origin for Antarctic shelf bedforms with special attention to megalineations ", Geomorphology 102, 364-375, Geomorphology, 117(1-2), 195-198, doi:10.1016/j.geomorph.2009.09.036.

Patterson, C. J., and R. Hooke (1995), Physical environment of drumlin formation, J. Glaciol., 41(137), 30-38.

Phillips, E., J. D. Everest, and D. Diaz-Doce (2010), Bedrock controls on subglacial landform distribution and geomorphological processes: Evidence from the Late Devensian Irish Sea Ice Stream, Sediment. Geol. , 232(3-4), 98-118, doi:10.1016/j.sedgeo.2009.11.004.

Podwysocki, M. H., J. G. Moik, and W. C. Shoup (1975), Quantification of geologic lineaments by manual and machine processing techniques., NASA Earth Resour. Symp., Houston, Texas, June 1975. 1 July.

Rabassa, J. (1987), Drumlins and drumlinoid forms in northern James Ross Island, Antarctic Peninsula, in Drumlin Symposium, edited by J. Menzies and J. Rose, pp. 103-115, Balkema, Rotterdam.

Rappaport, Y., D. F. Naar, C. C. Barton, Z. L. Liu, and R. N. Hey (1997), Morphology and Distribution of Seamounts Surrounding Easter Island, J. Geophys. Res., 102, 24713-24728.

Rose, J. (1987), Drumlins as part of a glacier bedform continuum, in Drumlin Symposium, edited by J. Menzies and J. Rose, pp. 103-116, Balkema, Rotterdam.

Rose, J. (1989), Glacier sediment patterns and stress transfer associated with the formation of superimposed flutes, Sediment. Geol., 62, 151-176.

Scheirer, D. S., and K. C. Macdonald (1995), Near-axis seamounts on the flanks of the East Pacific Rise, 8N to 17N, Mar. Geophys. Res., 100, 2239-2259.

Shaw, J. (1983), Drumlin formation related to inverted melt-water erosional marks, J. Glaciol., 29(103), 461-479.

Siegal, B. S., and N. M. Short (1977), Significance of operator variation and the angle of illumination in lineament analysis on synoptic images, LANDSAT Geol. Investig.

Sithole, G., and G. Vosselman (2004), Experimental comparison of filter algorithms for bareEarth extraction from airborne laser scanning point clouds, ISPRS J. Photogramm. Remote Sens., 59, 85--101.

Smalley, I., and D. Unwin (1968), The formation and shape of drumlins and their distribution and orientation in drumlin fields, J. Glaciol., 7(51), 377-390.

Smalley, I., and J. Warburton (1994), The shape of drumlins, their distribution in drumlin fields, and the nature of the sub-ice shaping forces, Sediment. Geol., 91, 241-252.

Smith, A. M., and T. Murray (2009), Bedform topography and basal conditions beneath a fastflowing West Antarctic ice stream, Quat. Sci. Rev., 28, 584-596.

Smith, A. M., T. Murray, K. W. Nicholls, K. Makinson, G. Athalgerirdottir, A. Behar, and D. G. Vaughan (2007), Rapid erosion and drumlin formation observed beneath a fast-flowing Antarctic ice stream, Geology, 35, 127-130.

Smith, D. K., and T. H. Jordan (1987), The size distribution of Pacific seamounts, Geophys. Res. 
1060

1061

1062

1063

1064

1065

1066

1067

1068

1069

1070

1071

1072

1073

1074

1075

1076

1077

1078

1079

1080

1081

1082

1083

1084

1085

1086

1087

1088

1089

1090

1091

1092

1093

1094

1095

1096

1097
Lett., 14(11), 1119-1122.

Smith, M. J., and C. D. Clark (2005), Methods for the visualization of digital elevation models for landform mapping, Earth Surf. Process. Landforms, 30(7), 885-900, doi:10.1002/esp.1210.

Smith, M. J., J. Rose, and S. Booth (2006), Geomorphological mapping of glacial landforms from remotely sensed data: an evaluation of the principal data sources and an assessment of their quality, Geomorphology, 76, 148-165.

Smith, M. J., J. Rose, and M. B. Gousie (2009), The Cookie Cutter: A method for obtaining a quantitative 3D description of glacial bedforms, Geomorphology, 108, 209-218.

Spagnolo, M., C. D. Clark, and A. L. C. Hughes (2012), Drumlin relief, Geomorphology, 153-154, 179-191.

Stark, C. P., and N. Hovius (2001), The characterization of landslide size distributions, Geophys. Res. Lett., 28, 1091-1094.

Stokes, C. R., and C. D. Clark (2002), Are long subglacial bedforms indicative of fast ice flow?, Boreas, 31(3), 239-249.

Stokes, C. R., and C. D. Clark (2003), The Dubawnt palaeo-ice stream: evidence for dynamic ice sheet behaviour on the Canadian Shield and insights regarding the controls on ice stream location and vigour, Boreas, 32, 263-279.

Stokes, C. R., M. Spagnolo, and C. D. Clark (2011), The composition and internal structure of drumlins: complexity, commonality, and implications of a unifying theory of their formation, Earth Sci. Rev., 107(3-4), 398-422, doi:10.1016/j.earscirev.2011.05.001.

Stokes, C. R., M. Spagnolo, C. D. Clark, C. Ó Cofaigh, O. B. Lian, and R. B. Dunstone (2013a), Formation of mega-scale glacial lineations on the Dubawnt Lake Ice Stream bed: 1 . Size, shape and spacing from a large remote sensing dataset, Quat. Sci. Rev.

Stokes, C. R., A. C. Fowler, C. D. Clark, R. C. A. Hindmarsh, and M. Spagnolo (2013b), The instability theory of drumlin formation and its explanation of their varied composition and internal structure, Quat. Sci. Rev., 62, 77-96.

Storrar, R., and C. R. Stokes (2007), A glacial geomorphological map of Victoria Island, Canadian Arctic., J. Maps, 3, 191-201, doi:10.1080/jom.2007.9710838.

Wasserstein, R. L., and N. A. Lazar (2016), The ASA's statement on p-values: context, process, and purpose, Am. Stat., 70(2), 129-133. 
1098

1099

1100

1101

1102

1103

1104

1105

1106

1107

1108

1109

1110

1111

1112

1113

1114

1115

1116

1117

Table 1: Parameters of the drumlin data from Múlajökull. Shading indicates a statistical significance of differences; light shading $P<0.1$, dark shading $P<0.05$. Bold numbers indicate if skew is different from $0(P<0.05)$. Uncertainties are $1 \sigma$, and tests 1 -tailed. Note that all parameters are estimated from the underlying data, and binning for visualization (i.e. Figure 7) is solely for that purpose.

\begin{tabular}{|c|c|c|c|c|c|c|c|c|c|c|}
\hline \multirow[t]{2}{*}{ Distribution } & \multirow[t]{2}{*}{${ }^{4}$ Parameter } & \multicolumn{3}{|c|}{${ }^{2} \mathrm{H}$} & \multicolumn{3}{|c|}{$L$} & \multicolumn{3}{|c|}{$w$} \\
\hline & & Inside & & Outside & Inside & & Outside & Inside & & Outside \\
\hline \multirow[t]{4}{*}{ Normal } & \multirow[t]{2}{*}{${ }^{3} \mu(m)$} & 7.6 & \multirow[t]{2}{*}{$\approx$} & \multirow{2}{*}{$\begin{array}{r}7.4 \\
\pm 0.3 \\
\end{array}$} & 219.5 & \multirow[t]{2}{*}{$>$} & 168.9 & 80.5 & \multirow[t]{2}{*}{$<$} & 93.8 \\
\hline & & \pm 0.3 & & & \pm 9.4 & & \pm 5.8 & \pm 2.7 & & \pm 4.0 \\
\hline & \multirow{2}{*}{ skew } & 0.258 & & 0.193 & 0.861 & & 0.764 & 0.228 & \multirow[t]{2}{*}{$<$} & 1.011 \\
\hline & & \pm 0.153 & & \pm 0.214 & \pm 0.379 & & \pm 0.248 & \pm 0.250 & & \pm 0.397 \\
\hline \multirow{4}{*}{ Log-Normal } & \multirow[t]{2}{*}{$\mu_{\mathrm{L}}$} & 1.963 & & 1.940 & 5.373 & $>$ & 5.099 & 4.342 & \multirow{2}{*}{$<$} & 4.495 \\
\hline & & \pm 0.045 & & \pm 0.048 & \pm 0.041 & & \pm 0.033 & \pm 0.036 & & \pm 0.041 \\
\hline & \multirow[t]{2}{*}{$\sigma_{\mathrm{L}}$} & 0.393 & & 0.354 & 0.362 & $>$ & 0.245 & 0.315 & & 0.303 \\
\hline & & \pm 0.032 & & \pm 0.043 & \pm 0.029 & & \pm 0.021 & \pm 0.027 & & \pm 0.031 \\
\hline \multirow[t]{5}{*}{ Gamma } & \multirow[t]{2}{*}{$\alpha$} & 7.270 & & 9.029 & 8.074 & $<$ & 16.908 & 11.046 & \multirow{2}{*}{\multicolumn{2}{|c|}{$\begin{array}{c}11.201 \\
\pm 2.103 \\
\end{array}$}} \\
\hline & & \pm 1.146 & & \pm 1.691 & \pm 1.265 & & \pm 3.186 & \pm 1.753 & & \\
\hline & \multirow[t]{2}{*}{$\beta$} & 0.952 & & 1.226 & 0.035 & \multirow[t]{2}{*}{$<$} & 0.100 & 0.137 & \multirow{2}{*}{\multicolumn{2}{|c|}{$\begin{array}{l}0.119 \\
\pm 0.023\end{array}$}} \\
\hline & & \pm 0.155 & & \pm 0.236 & \pm 0.006 & & \pm 0.019 & \pm 0.022 & & \\
\hline & ${ }^{1} \phi$ (i.e. mode) & 6.3 & & 6.4 & 210.5 & & 161.6 & 72.3 & & 82.5 \\
\hline \multirow[t]{2}{*}{ Exponential } & \multirow[t]{2}{*}{${ }^{3} \lambda$} & 0.359 & & 0.417 & 0.013 & $<$ & 0.026 & 0.046 & \multirow[t]{2}{*}{$>$} & 0.032 \\
\hline & & \pm 0.050 & & \pm 0.072 & \pm 0.002 & & \pm 0.005 & \pm 0.007 & & \pm 0.006 \\
\hline Non-parametric & ${ }^{5}$ median & 7.5 & & 7.0 & 220 & $>$ & 164 & 79 & $<$ & 85 \\
\hline
\end{tabular}

${ }^{1}$ estimated from the Gamma distribution as Hillier et al. [2013], but using maximum likelihood estimates. Derived from $\alpha$ and $\beta$ so significance of any differences not estimated.

${ }^{2} 1992$ and 2008 moraines removed if $H$ increased by $>2 \mathrm{~m}$

${ }^{3}$ Significance calculated using Welsh t-test, 2 -tailed; $1 / \lambda$ is a mean [e.g. see Hillier et al., 2013].

${ }^{4}$ Unless otherwise stated, significance by non-parametric bootstrapping; resampling is with replacement within sub-sets, $n=10,000$.

${ }^{5}$ Two-sample Wilcoxon test; strictly, a non-parametric test of difference in distribution location, not difference in medians, but it is a useful and relevant indicator. 
1118 Table 2: Means of the logarithms of size data (i.e. $\mu_{\mathrm{L}}$ ) for various global data, both before and

1119 after a conservative correction for the completeness of mapping is applied i.e. Fig. 1c of [Hillier

1120 et al., 2014].

1121

\begin{tabular}{|c|c|c|c|c|c|c|c|c|}
\hline \multirow{2}{*}{ Data Set } & Flow & \multicolumn{6}{|c|}{ Before } & \multicolumn{3}{|c|}{ After } \\
\cline { 2 - 9 } & Set ID & $\mathbf{n}$ & $\boldsymbol{H}$ & $\mathbf{L}$ & $\boldsymbol{W}$ & $\boldsymbol{H}$ & $\boldsymbol{L}$ & $\boldsymbol{W}$ \\
\hline \multirow{4}{*}{ [Ely et al., 2017] } & 9 & - & - & 6.034 & - & - & 5.997 & - \\
\cline { 2 - 9 } & 10 & 976 & 1.808 & 6.656 & 5.495 & 1.527 & 6.621 & 5.520 \\
\cline { 2 - 9 } & 15 & 471 & 1.895 & 6.334 & 5.323 & 1.631 & 6.314 & 5.338 \\
\cline { 2 - 9 } & 23 & 461 & 1.868 & 6.217 & 5.318 & 1.632 & 6.206 & 5.336 \\
\cline { 2 - 9 } & 29 & 1473 & 1.856 & 5.720 & 4.913 & 1.671 & 5.691 & 4.904 \\
\cline { 2 - 9 } & 40 & 239 & 2.090 & 5.920 & 5.123 & 1.933 & 5.883 & 5.126 \\
\cline { 2 - 9 } & 45 & 1407 & 1.639 & 6.293 & 5.195 & 1.358 & 6.273 & 5.201 \\
\cline { 2 - 9 } & 65 & 152 & 1.807 & 6.441 & 5.503 & 1.563 & 6.453 & 5.533 \\
\hline $\begin{array}{c}\text { [Hillier and Smith, 2012] } \\
\text { Loch Lomond, UK }\end{array}$ & - & 173 & 1.505 & 5.819 & 4.547 & 1.101 & 5.723 & 4.405 \\
\hline $\begin{array}{c}\text { [Clark et al., 2009] } \\
\text { UK, aggregated }\end{array}$ & - & 37043 & - & 6.263 & 5.271 & - & 6.208 & 5.288 \\
\hline $\begin{array}{c}\text { [Spagnolo et al., 2012] } \\
\text { UK, aggregated }\end{array}$ & - & 25848 & 1.728 & - & - & 1.446 & - & - \\
\hline $\begin{array}{c}\text { [Dowling et al., 2015] } \\
\text { Sweden, aggregated }\end{array}$ & - & 20,041 & 1.255 & 5.704 & 4.380 & 1.006 & 5.573 & 4.314 \\
\hline
\end{tabular}

1122

1123

1124

1125 
Figure Captions

1127

1128

1129

1130

1131

1132

1133

1134

1135

1136

1137

1138

1139

1140

1141

1142

1143

1144

1145

1146

1147

1148

1149

1150

1151

1152

1153

1154

1155

1156

1157

1158

1159

Figure 1: The typical shape of size-frequency distributions for mapped drumlins. These probability density functions are similar to normalized histograms, and are plotted on semi-log axes for graphical purposes (i.e. an exponential distribution plots as a straight line). a) Sizefrequency data for two studies, as black dots [Clark et al., 2009] and a grey line [Hillier and Smith, 2012], illustrated with length. Selected statistical distributions are fitted to them: exponential distribution (solid blue line); gamma distribution (dashed line) [Hillier et al., 2016]; log-Normal (dotted lines)[Fowler et al., 2013]. b) The typical distribution shape [Hillier et al., 2013], with possible explanations for it annotated in bold text next to the part of the distribution they may impact.

Figure 2: Recovery rate (i.e. 'completeness') as a function of size, with the use of realistic synthetic DEMs allowing absolute values for recovery to be determined [Hillier et al., 2014]. Solid black line is for height, $H$, and grey lines are for width $W$ (solid) and length $L$ (dashed). Circles are means, shown with their standard errors across 10 synthetic DEMs. Dashed black line is for medians for $H . H, W$, and $L$ have bin widths of 2.5, 25 and $100 \mathrm{~m}$, respectively. At the upper end, bins with two or fewer input data are omitted, giving maxima of 20, 275 and $800 \mathrm{~m}$, respectively. All data are plotted centrally within bins.

Figure 3: a) Location of Múlajökull (white square) on the southern edge of the Hofsjökull ice cap. b) Overview photograph, July 2011, with view from the SE. Photo courtesy of Sverrir A. Jónsson. c) Múlajökull glacier and surrounding area, adapted from Benediktsson et al. [2016], who also detail the data and mapping methods. Background map is the 2013 LiDAR hillshade in a mosaic with 2014 orthophotos. Drumlins (red with white outlines) are all within limits of the 2013 LiDAR data coverage. P1 and P2 are terrain profiles shown in Figure 5. The LIA, 1992, 2008 and 2013 ice limits are labelled. Dashed white line on ice surface indicates the approximate edge of the overdeepening beneath Múlajökull and the up-glacier limit of the drumlin field [Lamsters et al., 2016]. UTM (zone 27N) coordinates used. d) A drumlin emerging from the central margin of Múlajökull in 2014. Ice flow is towards the viewer.

Figure 4: a) Extract from a 2014 orthophoto showing the sparsely to non-vegetated area inside the LIA moraine and the contrast to continuous vegetation beyond it. b) Extract from a 2015 URL: http://mc.manuscriptcentral.com/sgff Email: Christian.Skovsted@nrm.se 
1160 high-resolution orthophoto recorded with an unmanned air vehicle showing exposed and non-

1161 vegetated drumlins in front of the ice margin in 2015 (photo courtesy of Jez Everest, British

1162 Geological Survey). c) View of the distal slope of the LIA terminal moraine, exemplifying the

1163 continuous but low vegetation on and beyond the moraine. Ice flow was from left to right. The

1164 location of the photograph is indicated with a black asterisk on a).

1165

1166 Figure 5: Profiles illustrating DEM data quality of the 2008 (grey line) and 2013 (black line) 1167 LiDAR surveys, and stability through time of the till plain. Spatial extent is limited to inside the 11681992 moraine as the 2008 data only extend that far. Thin vertical lines are the limits of the 1169 numerical comparison, dashed lines the trends fitted by ordinary least squares to the 2013 data, 1170 and grey horizontal bars indicate where 2013 heights are 'high' (i.e. above the trend).

1171

1172 Figure 6: Elevation change between 2008 and 2013 LiDAR DEMs where they overlap (i.e. inside

1173 the 1992 moraine). All changes shown in colour are decreases in elevation, whilst greys within 1174 the polygon of coincident LiDAR are increases. Black and blue solid lines show the 2008 and 11752013 ice margins, respectively. Background map is the 2013 LiDAR hillshade. Profiles in Figure 5 1176 are P1 and P2. Coordinate system is UTM zone 27.

Figure 7: Semi-log size-frequency plots for $H, W, L$ for inside (a-c) and outside (d-f) the 1992 moraine at Múlajökull with exponential (grey line), Gamma (blue dashed line) and log-Normal (pale blue dotted line) distributions fitted. Data (black dots) are from Benediktsson et al. [2016] ( $H, W, L$ triplets given in Supplementary Material), binned to illustrate the empirical density function, and distribution parameters are in Table 1. Extent to which a conservative correction for detectability and mapping ability (i.e. Figure 2 or Fig. 1c of [Hillier et al., 2014]) can influence the exponential model is shown as a grey dashed line.

Figure 8: Potential for incomplete mapping to explain the roll-over in a) height, b) length, and c) width for aggregated UK data [Clark et al., 2009; Spagnolo et al., 2012]. Data are black dots. Plots are semi-log and of count density, with an exponential model fitted to drumlins larger than the mode as Hillier et al. [2013] (grey line). Exponent is $\lambda$. Extent to which a conservative correction (i.e. Figure 2 or Fig. 1c of [Hillier et al., 2014]) can influence this model is show (grey dashed line); if dashed line descends below the data at smaller sizes this indicates a potential magnitude exceeding that of the roll-over. 
1194 Figure 9: Potential for incomplete of mapping to explain the roll-over in a) height, b) length, and 1195 c) width for drumlins near Loch Lomond [Hillier and Smith, 2012].

1196

1197

Figure 10: Potential for incomplete of mapping to explain the roll-over in a) height, b) length, and c) width for drumlins Swedish drumlins; extended dataset based on Dowling et al. [2015]. d), e) and f) expand section of these plots around the roll-over. Exponential (grey line), Gamma (blue dashed line) and log-Normal (pale blue dotted line) distributions fitted. Possible correction for detectability is as in Figure 7.

Figure 11: Probability distributions for log-transformed heights $(H)$ for selected UK flow sets 1204 from Ely et al. [2017] (Fig. 7f), in which a Gaussian shape illustrates a log-Normal distribution. a) 1205 is uncorrected observations, whilst b) has had the under-sampling correction applied. 

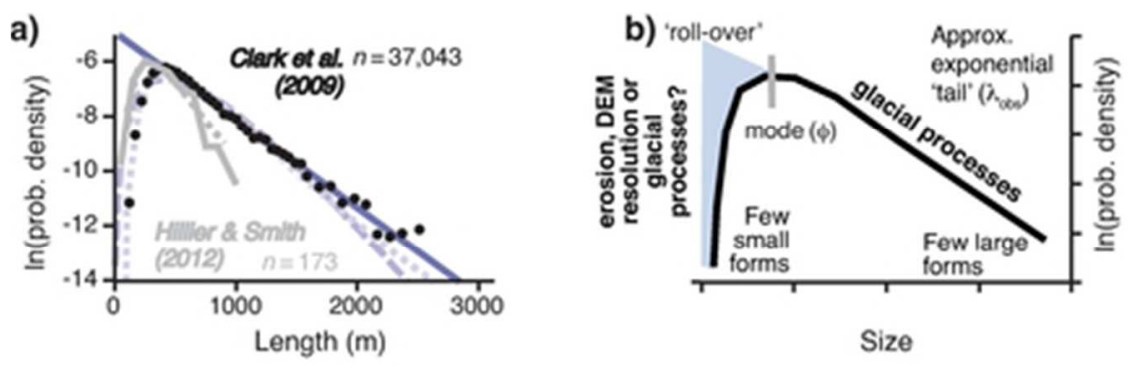

$36 \times 11 \mathrm{~mm}(300 \times 300$ DPI) 


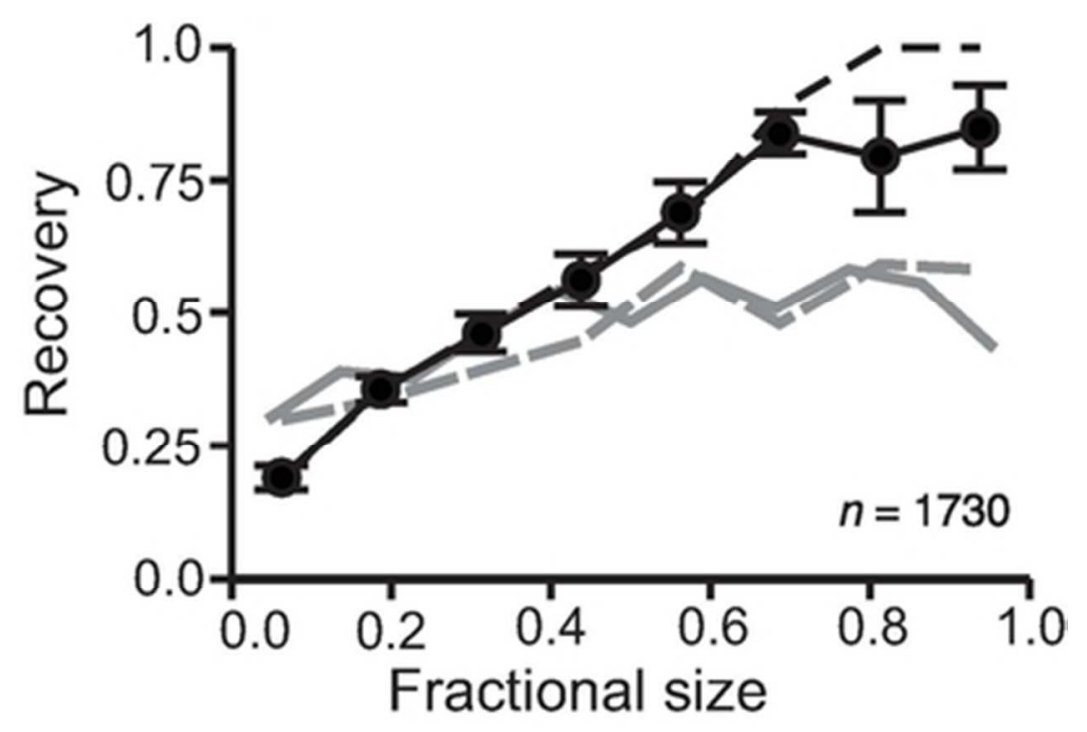

$34 \times 23 \mathrm{~mm}(300 \times 300 \mathrm{DPI})$ 

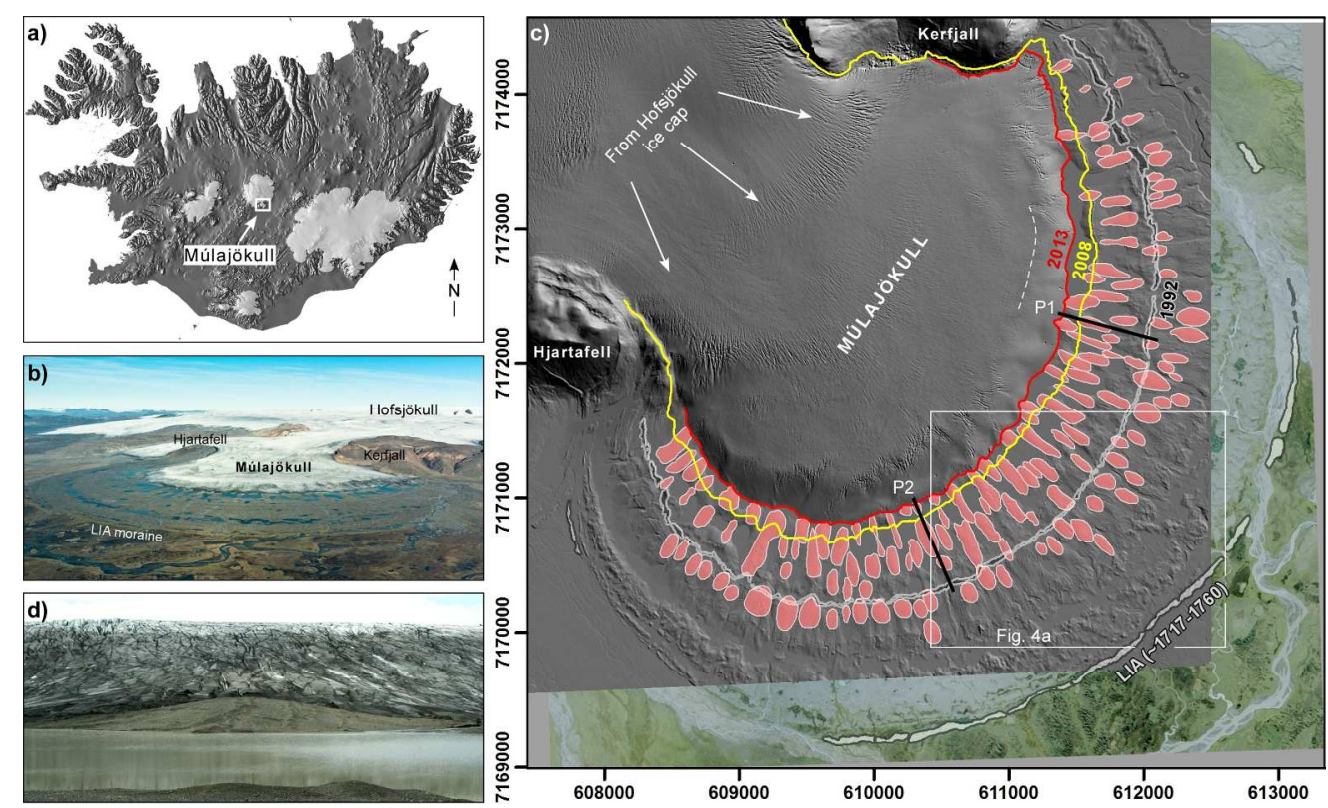

$205 \times 124 \mathrm{~mm}(300 \times 300 \mathrm{DPI})$ 

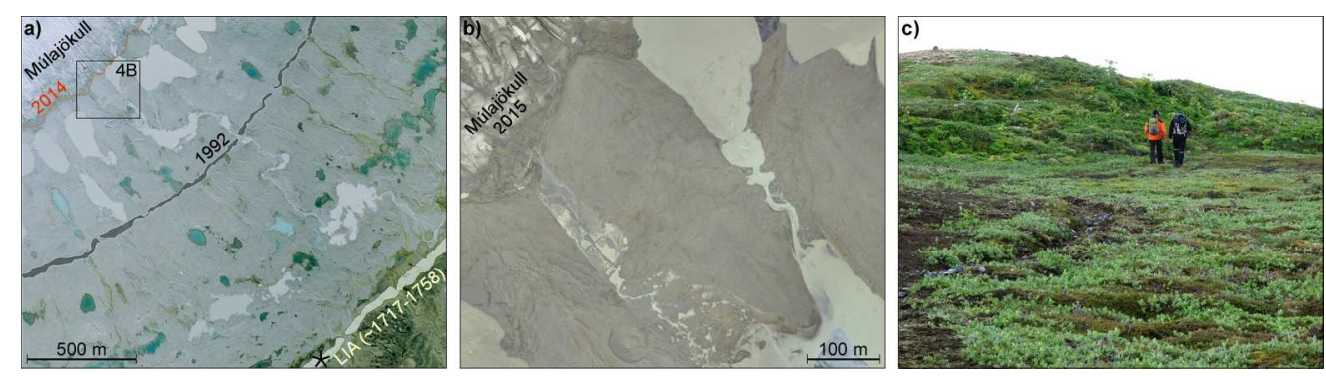

$180 \times 48 \mathrm{~mm}(300 \times 300 \mathrm{DPI})$ 

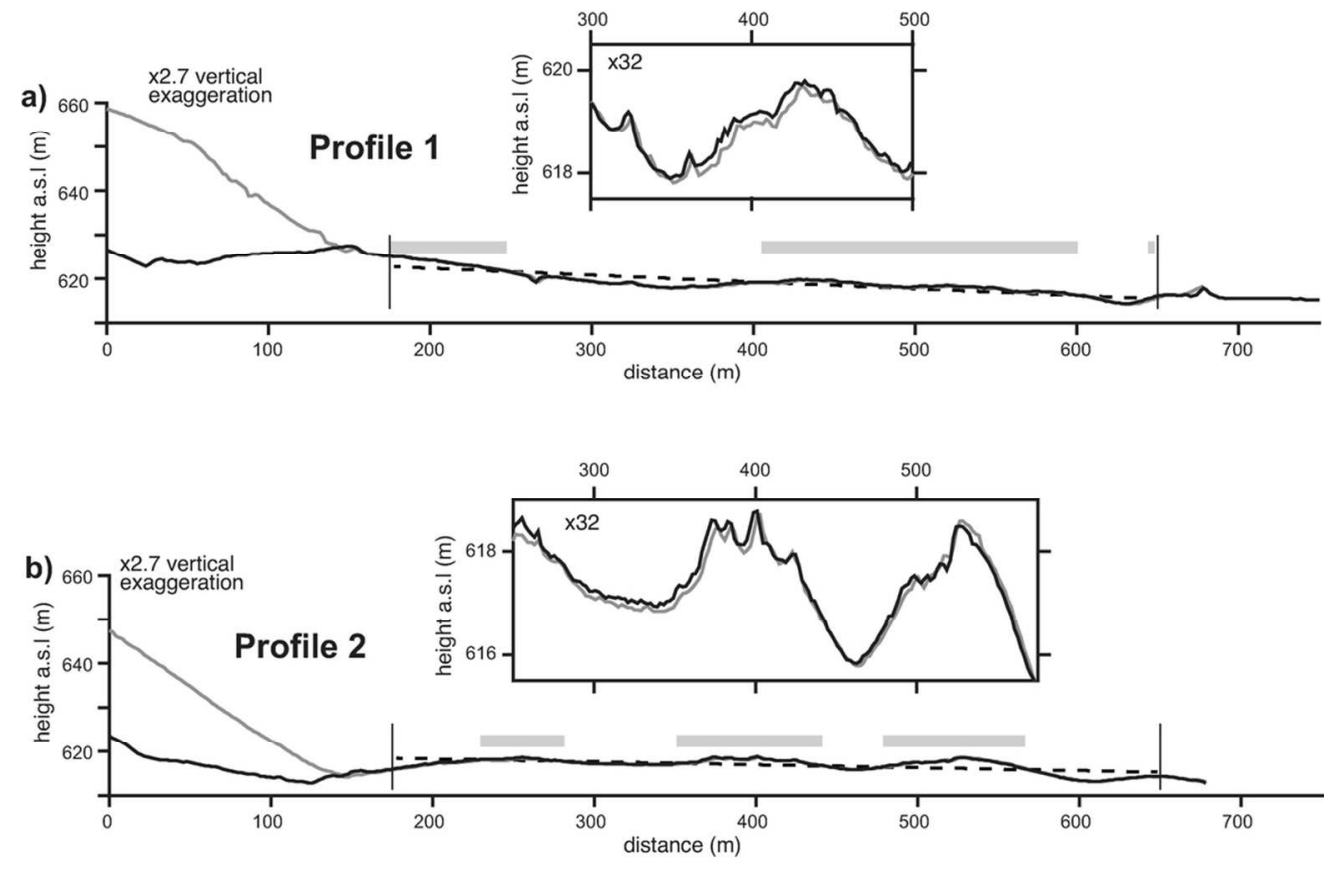

$98 \times 64 \mathrm{~mm}(300 \times 300 \mathrm{DPI})$ 


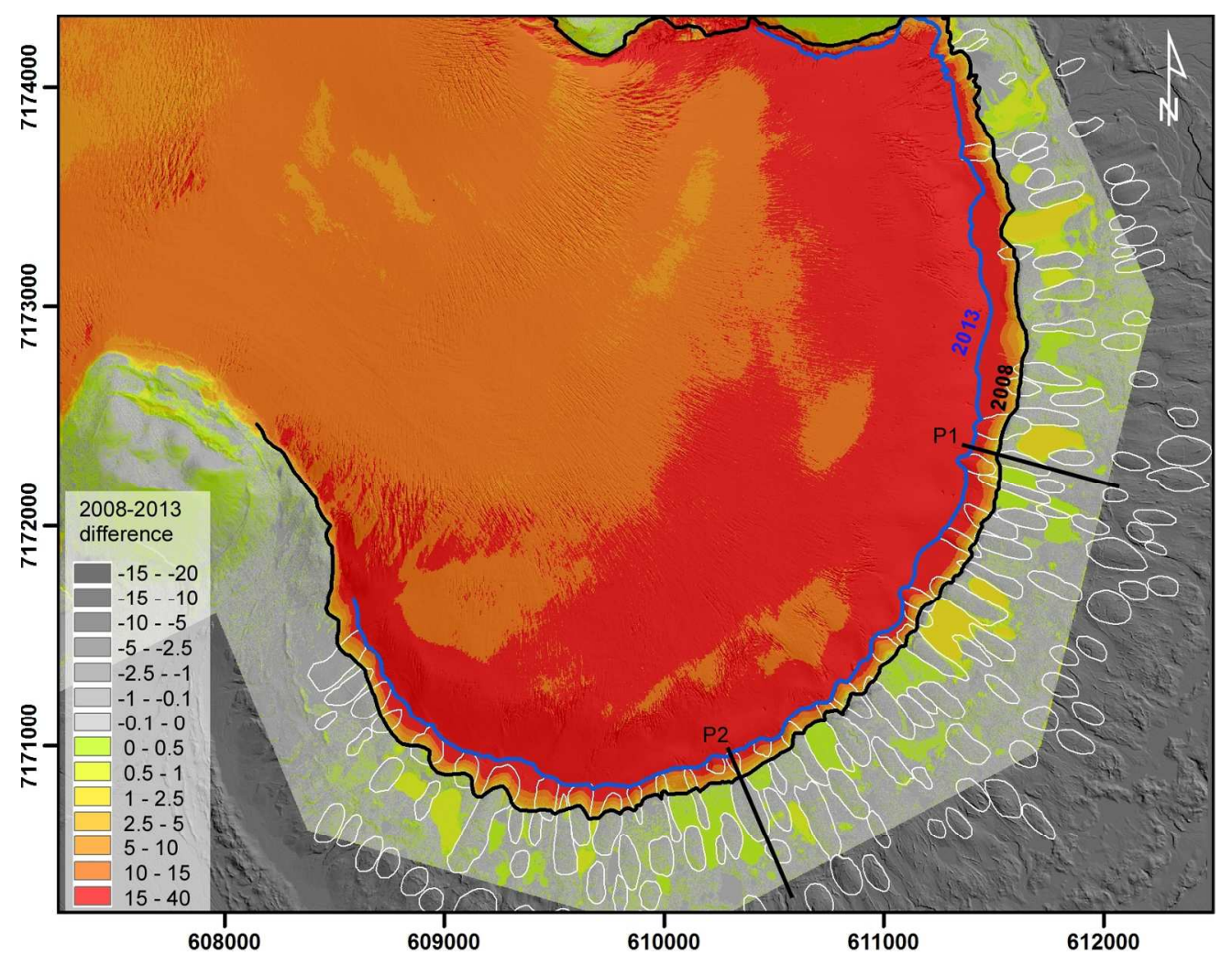

$157 \times 123 \mathrm{~mm}(300 \times 300$ DPI $)$ 

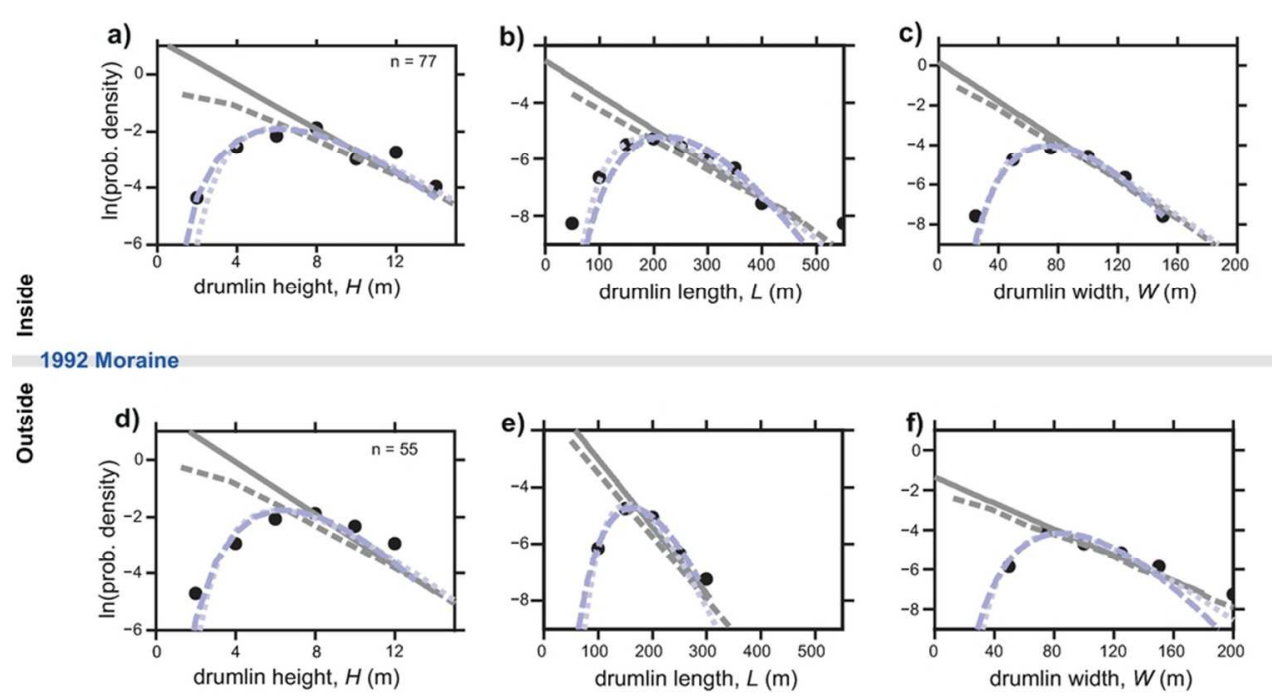

$86 \times 44 \mathrm{~mm}(300 \times 300$ DPI $)$

URL: http://mc.manuscriptcentral.com/sgff Email: Christian.Skovsted@nrm.se 

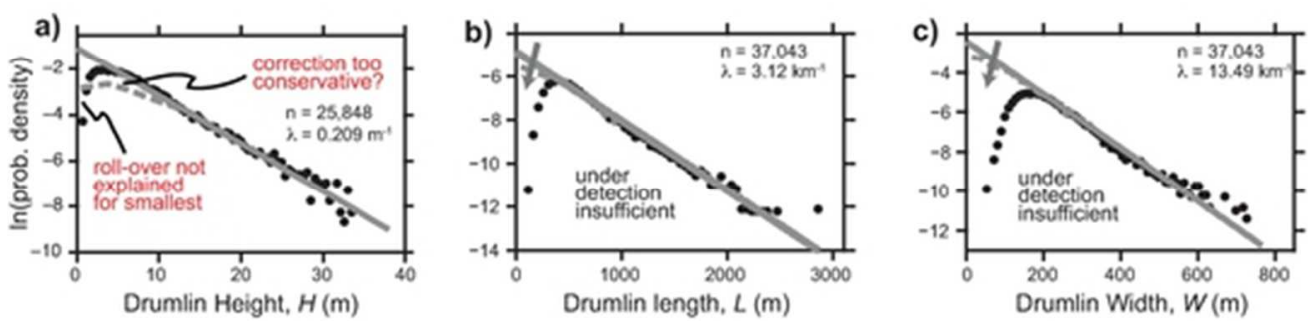

$45 \times 13 \mathrm{~mm}(300 \times 300$ DPI $)$ 

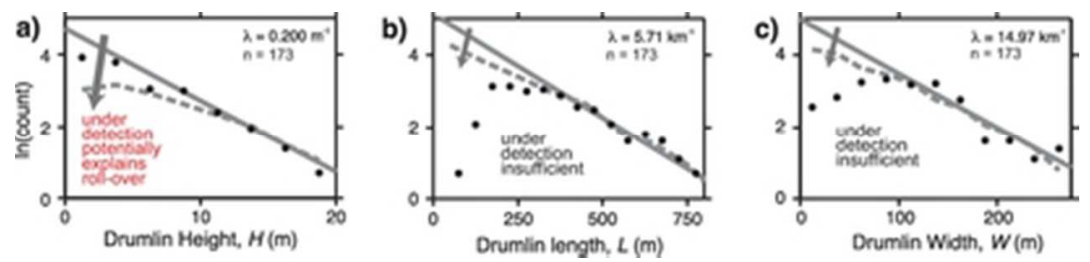

$34 \times 7 \mathrm{~mm}(300 \times 300 \mathrm{DPI})$

15

17

18

19

20

21

22

23

24

25

26

27

28

29

30

31

32

33

34

35

36

37

38

39

40

41

42

43

44

45

46

47

48

49

50

51

52

53

54

55

56

57

58

59

60

URL: http://mc.manuscriptcentral.com/sgff Email: Christian.Skovsted@nrm.se 


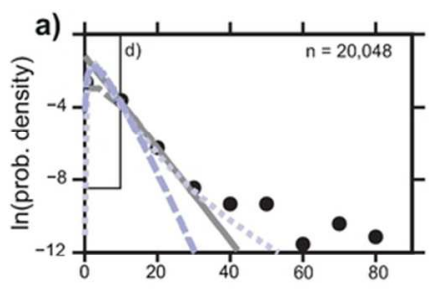

b)

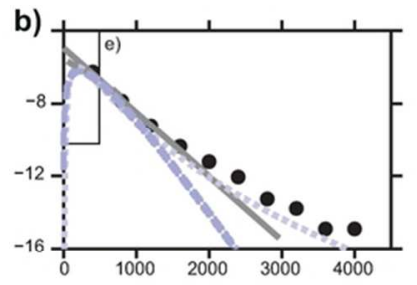

e)
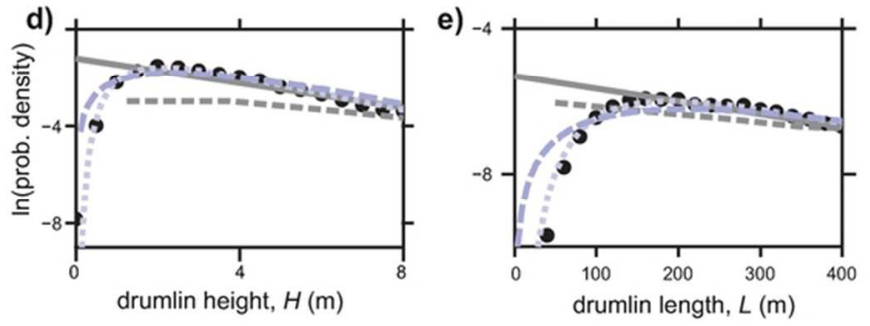

$71 \times 33 \mathrm{~mm}(300 \times 300 \mathrm{DPI})$
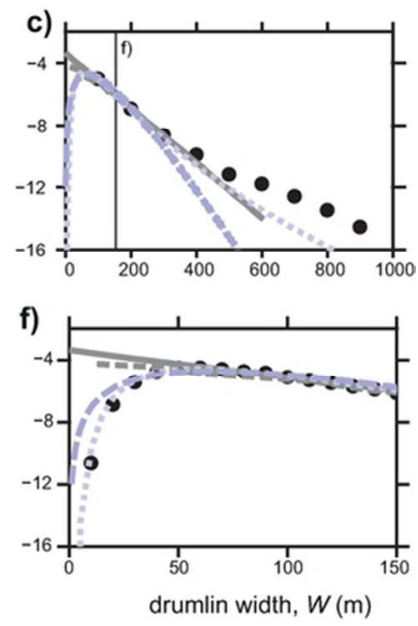

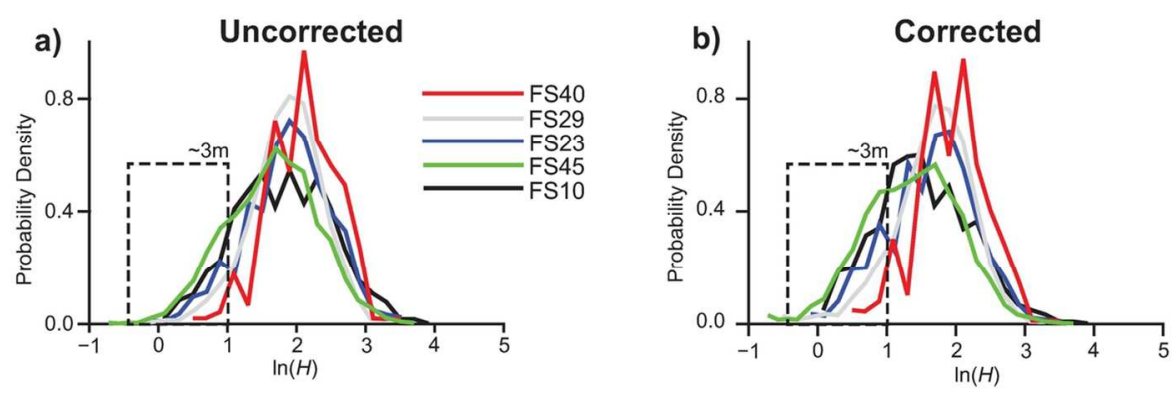
Drumlins INSIDE the 1992 moraine

Height (H), Width (W) and Length (L) triplets for the 132 fully exposed drumlins as mapped and estimated by Benediktsson et al (2016). Each HWL triplet is on a row. 77 drumlins.

All measurements are in metres.

Benediktsson et al [2016] Boreas, 45, 567-583.

Column $1=$ Height $(\mathrm{m})$

Column 2 = Width $(\mathrm{m})$

Column 3 = Length $(\mathrm{m})$

$8.20059 .000 \quad 169.000$

4.60028 .000117 .000

$2.600 \quad 41.000 \quad 74.000$

$9.20086 .000 \quad 166.000$

$4.300 \quad 47.000 \quad 145.000$

$8.100 \quad 93.000 \quad 133.000$

$7.200 \quad 80.000 \quad 250.000$

$6.10078 .000 \quad 165.000$

6.30074 .000220 .000

$9.200 \quad 99.000 \quad 275.000$

$7.000 \quad 79.000 \quad 278.000$

$4.90078 .000 \quad 164.000$

$\begin{array}{lll}7.700 & 95.000 \quad 320.000\end{array}$

$5.900 \quad 68.000 \quad 239.000$

$11.900118 .000 \quad 236.000$

$9.000 \quad 75.000 \quad 305.000$

$7.800 \quad 67.000 \quad 200.000$

$12.100 \quad 75.000 \quad 254.000$

$8.900 \quad 46.000 \quad 349.000$

$4.100 \quad 63.000 \quad 133.000$

$5.700 \quad 74.000 \quad 236.000$

$12.400 \quad 82.000 \quad 267.000$

$3.000 \quad 40.000 \quad 162.000$

$6.900 \quad 67.000 \quad 216.000$

$8.500 \quad 80.000 \quad 273.000$

$5.600 \quad 67.000 \quad 184.000$

8.70078 .000262 .000

$7.800 \quad 76.000 \quad 335.000$

$11.700 \quad 107.000 \quad 368.000$

$7.000 \quad 62.000 \quad 220.000$

$8.100 \quad 77.000 \quad 251.000$

$8.000 \quad 96.000 \quad 384.000$

$\begin{array}{llll}7.700 & 62.000 & 192.000\end{array}$

$7.700 \quad 86.000 \quad 244.000$

$4.100 \quad 51.000 \quad 179.000$

$6.800 \quad 83.000 \quad 206.000$

$7.500 \quad 102.000 \quad 225.000$

$10.300 \quad 103.000 \quad 354.000$

$8.900 \quad 95.000 \quad 221.000$

$11.500 \quad 115.000 \quad 361.000$

$2.500 \quad 47.000 \quad 144.000$

7.20085 .000259 .000

$3.800 \quad 57.000 \quad 116.000$

$11.400 \quad 95.000 \quad 344.000$

6.600101 .000276 .000

$5.300 \quad 63.000185 .000$ 


$\begin{array}{lll}6.900 & 98.000 & 122.000 \\ 3.300 & 55.000 & 160.000 \\ 8.400 & 115.000 & 381.000 \\ 4.900 & 77.000 & 217.000 \\ 6.700 & 128.000 & 323.000 \\ 6.100 & 92.000 & 218.000 \\ 5.800 & 43.000 & 132.000 \\ 11.400 & 43.000 & 292.000 \\ 7.800 & 88.000 & 214.000 \\ 11.600 & 54.000 & 319.000 \\ 5.900 & 109.000 & 180.000 \\ 7.200 & 101.000 & 135.000 \\ 5.000 & 68.000 & 175.000 \\ 8.800 & 97.000 & 250.000 \\ 7.900 & 80.000 & 192.000 \\ 9.200 & 113.000 & 267.000 \\ 10.800 & 113.000 & 283.000 \\ 9.100 & 107.000 & 372.000 \\ 4.700 & 79.000 & 123.000 \\ 7.300 & 54.000 & 156.000 \\ 6.500 & 93.000 & 191.000 \\ 3.400 & 65.000 & 167.000 \\ 11.500 & 150.000 & 545.000 \\ 10.500 & 99.000 & 184.000 \\ 13.100 & 70.000 & 193.000 \\ 5.700 & 59.000 & 153.000 \\ 6.000 & 83.000 & 166.000 \\ 13.100 & 96.000 & 220.000 \\ 12.400 & 86.000 & 257.000 \\ 3.800 & 54.000 & 116.000 \\ 13.400 & 127.000 & 311.000\end{array}$


Drumlins OUTSIDE the 1992 moraine

Height (H), Width (W) and Length (L) triplets for the 132 fully exposed drumlins as mapped and estimated by Benediktsson et al (2016). Each HWL triplet is on a row. 55 drumlins.

All measurements are in metres.

Benediktsson et al [2016] Boreas, 45, 567-583.

Column 1 = Height $(\mathrm{m})$

Column 2 = Width $(\mathrm{m})$

Column $3=$ Length $(\mathrm{m})$

$6.000 \quad 54.000 \quad 138.000$

$10.000 \quad 77.000 \quad 146.000$

$7.000 \quad 77.000 \quad 140.000$

$7.000 \quad 100.000 \quad 176.000$

$4.000 \quad 70.000 \quad 112.000$

$4.00084 .000 \quad 186.000$

$2.000 \quad 46.000 \quad 110.000$

$6.000 \quad 69.000 \quad 232.000$

$5.000 \quad 68.000 \quad 126.000$

$6.000 \quad 78.000 \quad 179.000$

$9.000 \quad 69.000 \quad 130.000$

$6.000 \quad 83.000 \quad 139.000$

$\begin{array}{llll}7.000 & 72.000 \quad 177.000\end{array}$

$10.000 \quad 133.000 \quad 241.000$

$9.000109 .000 \quad 281.000$

$4.000 \quad 65.000 \quad 109.000$

$7.000 \quad 65.000 \quad 192.000$

$9.000 \quad 74.000 \quad 132.000$

$4.000 \quad 41.000 \quad 106.000$

$12.000 \quad 138.000 \quad 286.000$

$5.000 \quad 85.000 \quad 141.000$

$4.000 \quad 82.000 \quad 140.000$

$8.000148 .000 \quad 205.000$

$\begin{array}{llll}7.000 & 79.000 \quad 153.000\end{array}$

$6.000 \quad 76.000 \quad 138.000$

$7.000 \quad 96.000 \quad 176.000$

$7.00080 .000 \quad 163.000$

$4.000 \quad 87.000 \quad 181.000$

$7.000 \quad 116.000 \quad 154.000$

$9.000 \quad 91.000 \quad 178.000$

$12.000 \quad 125.000 \quad 224.000$

$9.000 \quad 80.000 \quad 205.000$

$5.000 \quad 69.000 \quad 102.000$

$5.00077 .000 \quad 169.000$

$6.000 \quad 83.000 \quad 183.000$

$10.000 \quad 118.000 \quad 200.000$

$8.000 \quad 115.000 \quad 158.000$

$11.000 \quad 118.000 \quad 185.000$

$8.000 \quad 96.000 \quad 164.000$

$9.000 \quad 93.000 \quad 134.000$

$6.000124 .000 \quad 144.000$

$8.000132 .000 \quad 180.000$

$6.000 \quad 109.000 \quad 181.000$

$6.000 \quad 57.000 \quad 125.000$

$6.000 \quad 80.000 \quad 145.000$

$10.000 \quad 151.000 \quad 228.000$

URL: http://mc.manuscriptcentral.com/sgff Email: Christian.Skovsted@nrm.se 
$12.000 \quad 149.000 \quad 257.000$

$12.000 \quad 198.000 \quad 229.000$

$8.000 \quad 102.000 \quad 117.000$

$\begin{array}{llll}7.000 & 103.000 & 144.000\end{array}$

$8.000 \quad 95.000 \quad 146.000$

$9.000 \quad 95.000 \quad 180.000$

$8.000 \quad 75.000 \quad 166.000$

$11.000 \quad 97.000 \quad 201.000$

$7.000 \quad 104.000 \quad 154.000$ 